\title{
Religia, poznanie, duchowość w wychowaniu
}

Religion, Cognition, Spirituality

in Education

\begin{abstract}
ABSTRAKT
W artykule wychodzimy z założenia, że dla pedagogiki źródłem wiedzy o świecie i otaczajqcej go rzeczywistości nie jest wyłącznie wiedza empiryczna. Coraz częściej dochodzi do sprzeciwu wobec jednostronnego przypisywania wiedzy empirycznej priorytetu poznawczego. Obserwujemy też zwrot w kierunku pedagogiki heterogenicznej, która dopuszcza konkurujqce z sobq paradygmaty badawcze. Myślenie to umożliwia rozpatrywanie problemów pedagogicznych także w odniesieniu do transcendencji. Mówi się wówczas ○ „pedagogice transcendentnej”, identyfikowanej z autonomicznq subdyscyplinq nauki nazywanq ,pedagogikq religii”. W artykule podięto próby opisu wkładu religii w rzeczywistość pedagogiczno-wychowawczq. Mamy przy tym świadomość tego, że przedłożenie to nie będzie przez wszystkich akceptowane. Nie o to zreszta chodzi. Ważne jest natomiast, by niezależnie od prezentowanego światopoglaqdu szukać prawdy o znaczeniu religii w procesach rozwojowo-wychowawczych człowieka. Do poszukiwania prawdy niezbędna jest wiedza o tym, czy religia, właściwie rozumiana, ogranicza człowieka, czy też odsłania przed nim nowy, szerszy sens życia? Co religia (chrześcijaństwo) wnosi/może wnieść w życie człowieka i do czego może go inspirować? Uszczegóławiając zasygnalizowanq proble-
\end{abstract}

Articles and dissertations
SLOWA KLUCZOWE duchowość, pedagogika religii, poznanie religïne, religia, transcendencia

KEYWORDS

spirituality, pedagogy of religion, religious knowledge, religion, transcendence

SPI Vol. 20, 2017/2

ISSN 2450-5358

e-ISSN 2450-5366

DOI: 10.12775/SPI.2017.2.001

Artykuły i rozprawy 
matykę, zwrócimy uwagę na podpowiedź czerpanq z chrześcijaństwa, a odnoszqca się do rozumienia człowieka. Przedstawimy też ofertę jakq chrześcijaństwo składa pedagogice. Chodzi tu o wyjaśnienia zwiqzane z poznaniem innym niż empiryczne, a także o dowartościowanie i wspieranie w człowieku jego duchowości (sfery niematerialnej). Duchowość bywa nazywana zbiorem wartości, tradycii (dorobku kultury) i postaw człowieka. Przyjmuje się też, że kreśli on „drogę ludzkiego postępowania", promując wizję życia, refleksyjny stosunek do codzienności, nacechowane szacunkiem nastawienie do świata i nadzieję pełnego odnalezienia Boga (nieśmiertelności).

\section{ABSTRACT}

In this article we assume that empirical knowledge is not the only source of knowledge about the world and the surrounding reality for pedagogy. There is an increasing opposition to the unilateral assignment of cognitive priority to empirical knowledge and we can also see a shift towards heterogeneous pedagogy, which allows for competing research paradigms. This thinking enables us to also deal with pedagogical problems in relation to transcendence. We then speak of "transcendent pedagogy", identified with an autonomous subdiscipline of science called "pedagogy of religion." The article attempts to describe the contribution of religion to the pedagogical and educational reality. We are aware that this submission will not be accepted by all but this is not the point. It is important, however, that, regardless of the worldview, one should seek the truth about the importance of religion in the processes of human development and education. To find the truth it is necessary to know whether religion, properly understood, restricts man or if it reveals a new, more meaningful way of life to him. What does/ can religion (Christianity) bring into human life and what inspiration can it provide? Going into detail of the above-mentioned issues, we will engage the understanding of man drawn from Christianity. We will also present the offer that Christianity makes to pedagogy, by this meaning explanations based on non-empirical knowledge, as well as the appreciation and fostering human spirituality (the immaterial sphere). Spirituality is sometimes called a set of values, traditions (cultural heritage) and attitudes of man. It is also understood to outline the "path of human conduct" by promoting a vision of life, a reflective attitude toward everyday life, a respectful posture with regard to the world, and the hope of finding God (immortality). 
Jednym z charakterystycznych rysów pedagogiki końca XIX i połowy XX wieku było przekonanie o mocy wiedzy empirycznej ${ }^{1}$. Nie dostrzegano przy tym, zauważa Teresa Hejnicka-Bezwińska, że ten typ racjonalności może się obrócić przeciw człowiekowi. Sytuacja ta w znacznym stopniu uległa zmianie. Coraz częściej napotykamy sprzeciwy wobec prób monopolizacji, ortodoksji, dogmatyzacji, fundamentalizmu i innych tego typu zjawisk. Sprzeciw ten wyraża między innymi brak zgody na redukcję problematyki badawczej w pedagogice tylko do tego, co poddaje się pomiarowi empirycznemu. Następstwem tego myślenia jest odchodzenie od pedagogiki ortodoksyjnej i kierowanie się ku pedagogice heterogenicznej. W konsekwencji dopuszcza się istnienie konkurujących ze sobą paradygmatów nauki ${ }^{2}$. Idąc tym tokiem myślenia, Bogusław Śliwerski posługuje się pojęciem „pedagogiki transcendentnej”. Termin ten stoi na przeciwnym biegunie dość powszechnego przekonania, by pedagogikę uprawiać bez odniesień do transcendencji („pedagogika bez transcendencji”). Autor wyjaśnia, że

pedagogika bez transcendencji to pedagogika bez odwoływania się do wiary rozumianej jako obszaru Bożego objawienia, jako sfera tego, co jest dane, a na co wychowawcy i wychowankowie powinni się otwierać, to pedagogika bez mistyki, bez wskazywania na rolę doświadczenia transcendencji w ich życiu. Granicę tak rozumianych pedagogii wyznacza odpowiedź na pytanie, jakie prawdy one odkrywają i jakie chce się osiagnnąć cele przy ich pomocy ${ }^{3}$.

W przedłożeniu zamierzam skupić się na znaczeniu odwoływania się w rzeczywistości pedagogiczno-wychowawczej do religii, która wpisana jest we wszystkie kultury i która wciąż spełnia ważną rolę w życiu człowieka. Mam świadomość i tego, że rzeczywistość ta nie jest przez wszystkich akceptowana, a co zatem idzie często niedostrzegana. Konsekwentnie, przedłożenie to nie musi być przez wszystkich akceptowane. Nie o to zresztą chodzi. O wiele ważniejsze wydaje się być poszukiwanie, refleksja nad tym, czy rzeczywiście religia, właściwie rozumiana, ogranicza człowieka? A może odsłania przed nim nowy, szerszy sens życia? W kontekście założeń o tym,

\footnotetext{
Por. T. Hejnicka-Bezwińska, Pedagogika ogólna, Warszawa 2008, s. 318.

Tamże, s. 322-323.

B. Śliwerski, Pedagogika bez transcendencji, w: Pedagogika ignacjańska wobec wyzwañ wspótczesnego humanizmu, red. W. Pasierbek, Kraków 2008, s. 80-81.
} 
że nie tylko wiedza empiryczna kształtuje myślenie pedagogiczne, zapraszam do refleksji nad tym, co religia wnosi/może wnosić w procesy wychowania i do czego inspiruje?

\section{Religia}

Pośród wielu czynników kształtujących kulturę, a tym samym wpływających na sposób funkcjonowania człowieka, jest religia. Uważa się ją za pewnik, który człowiek poddaje doświadczeniư , a którego nie można wyrazić w pojęciach, zdaniach czy dowodzeniach. Religii nie można też demonstrować. Fakt ten nie przeszkadza, by człowiek odnajdywał w niej bezpieczeństwo i szczęście, a także by z jej pomocą dopasowywał się do realiów codziennego życia ${ }^{5}$. Jest ona czynnikiem, który otwiera i kieruje człowieka ku doskonałości, ku Transcendencji - Bogu. Relacja z Bogiem z kolei umożliwia szersze spojrzenie na nawiązywane przez człowieka inne relacje ${ }^{6}$.

Zjawiskiem charakterystycznym dla współczesnej kultury jest też zrywanie z religią i jej odrzucanie. Postawy takie są efektem nowych warunków życia, zmieniających się potrzeb egzystencjalnych człowieka oraz poszukiwań nowych form poznania Boga uniwersalnego ${ }^{7}$. Samo negowanie religii może wynikać z tego, że wciąż wielu uważa ją ciągle za swoiste tabu; nieistniejący problem, obok którego przechodzi się obojętnie czy wręcz wrogo ${ }^{8}$. Przekonanie to może wynikać z przeświadczenia, że Bóg istnieje tylko po to, by człowieka od siebie uzależniać, coś mu odebrać albo w czymś go ograniczyć9. Przyczyn

4 M.J. Buckley, Ateizm w sporze z religia, tłum. M. Frankiewicz, Kraków 2009, s. 239-241.

5 Por.J. Kunstmann, Rückehr der Religion. Glaube, Gott und Kirche neu verstehen, Gütersloh 2010, s. 32.

6 J.L. Griffith, M.E. Griffith, Odkrywanie duchowości w psychoterapii, tłum. K. Gdowska, Kraków 2008, s. 47.

7 Por. H. Zimoń, Typologia, w: Encyklopedia katolicka, t. 16, red. E. Gigilewicz $\mathrm{i}$ in., Lublin 2012, kol. 1394-1401.

8 F. Adamski, Personalistyczna wizja kultury, w: Pedagogika kultury - wychowanie do wyboru wartości, red. B. Żurakowski, Kraków 2003, s. 32-33.

9 Por. M.J. Buckley, Ateizm w sporze z religia, dz. cyt., s. 134-179. Autor wyjaśnia istotę tego nieporozumienia, ukazując, w jaki sposób na przestrzeni dziejów ludzie tworzyli pogląd, jakoby Bóg był przeciwnikiem człowieka. 
takiego nastawienia można znaleźć wiele. Jedną z nich jest przypisywanie Bogu właściwości, jakich On nie posiada i działań, których nie podejmuje. Najogólniej można mówić o niewłaściwym obrazie Boga, do czego wrócimy w dalszej części artykułu. Inni wyrażają z kolei obojętność wobec religii: nie są ani religijni, ani też nastawieni ateistycznie. W tej grupie siła tęsknoty za czymś doskonałym nie została całkowicie zniszczona. Jednak z powodu religijnego analfabetyzmu wielu nie może skorzystać z oferty religii, która uczy życia. Ceną, jaką człowiek płaci za próby oddzielenia kultury od religii, jest osamotnienie, lęk o siebie i swą przyszłośćc ${ }^{10}$.

Pomimo istniejących trendów laicyzacyjnych, obserwujemy też i inne zjawisko: duże „zapotrzebowanie” na religię. Dzieje się tak dlatego, że człowiek w religii dostrzega możliwość zaspokojenia swoich duchowych potrzeb poznania sensu własnego życia ${ }^{11}$. Trendy te potwierdzają badania przeprowadzone w latach 1999/2000. Wynika z nich, że 50,7\% Europejczyków wyraża przekonanie, że religia pełni „dość ważną” lub „bardzo ważną” rolę w ich życiu. Co więcej, $57,8 \%$ respondentów przyznaje, że z religii „czerpie pociechę i siłę” (49,9\% Niemców, 82\% Polaków) ${ }^{12}$. Owo „zapotrzebowanie” na religię jest więc wyrazem pojawiających się ludzkich niepokojów i zagrożeń ${ }^{13}$.

Samo zainteresowania religią nie zawsze jest skierowane ku osobowemu Bogu. Wielu wyraża potrzebę istnienia religii funkcjonującej bez Boga. Dzieje się tak wówczas, gdy człowiek w miejsce Boga wprowadza nowe panteistyczne czy też monistyczne wyobrażenia religijne ${ }^{14}$. Obserwujemy to $\mathrm{w}$ różnego rodzaju namiastkach religii (np. sport, kult pseudowartości). Wraz ze wspomnianym „zapotrzebowaniem” na

10 P.M. Zulehner, Religia jako mega trend, „Keryks” 2003, t. 2, nr 1, s. 23-24.

11 Por. J. Bagrowicz, Aksjomat wiary jako fundament oddziatywań dydaktyczno-wychowawczych, w: Wieloptaszczyznowe wsparcie cztowieka we wspótczesnej pedagogii. Ksiegga jubileuszowa dedykowana księdzu biskupowi Antoniemu Dtugoszowi, red. N. Pikuła, Kraków 2011, s. 143.

12 B. Grom, Psychologia religii, tłum. H. Machoń, Kraków 2009, s. 25.

13 H.-J. Fraas, Religia w procesie rozwoju osobowego dziecka, „Horyzonty Wiary” 1995, t. 6, nr 2, s. 45.

14 Por.: U.H.J. Körtner, Wiederhehr der Religion? Das Christentum zwischen neuer Spiritualität und Gottvergessenheit, Gütersloh 2006, s. 15; Z. Zdybicka, Transcendentne odniesienie cztowieka, w: Wychowanie personalistyczne. Wybór tekstów, red. F. Adamski, Kraków 2005, s. 83. 
religię pojawiają się także dążenia do subiektywnego objaśniania religii. Wielu uważa ją za osobiste odniesienie do czegoś innego i wyższego niż sam człowiek. Jest przy tym postrzegana jako rzeczywistość oparta na dwustronnych kontaktach z kimś (lub czymś), a jej przejawami stają się określone postawy i szczególna aktywność osoby.

Pojęcie „religia” jedni wyprowadzają z łacińskiego relegere, co znaczy „często zwracać się”, „skrupulatnie rozważać”. Inni wskazują na słowo religare, które oznacza „przywiązywać się”. Są i tacy, którzy wyprowadzają je od słowa reeligere, które znaczy „ponownie wybierać"15. Urlich Berner przywołuje chrześcijańskiego pisarza Laktancjusza, który termin „religia” wyprowadził z łacińskiego religare i tłumaczył jako „ponowne związanie człowieka z Bogiem”. Uważa, że wyjaśnienia Laktancjusza wykluczają znaczenia podawane przez Cycerona. Cyceron termin religio wyprowadzał od łacińskiego relegare i tłumaczył jako „skrupulatne oddawanie czci bogom” ${ }^{16}$. W kontekście tych wyjaśnień Zofia Zdybicka podkreśla, że w nowożytnych i współczesnych określeniach religii akcentuje się zwykle element subiektywny: poznawczy, wolitywny czy emocjonalny. $\mathrm{W}$ tym sensie religia jest swoistym, świadomym odniesieniem się człowieka do czegoś innego i wyższego niż on sam; kontaktem obustronnym z kimś (lub czymś), co przejawia się w określonej postawie i specjalnej aktywności ludzkiej.

Powyższe wyjaśnienia ukazują niemożność wypracowania jednolitej definicji religii. Wynika to przede wszystkim $z$ ich wielości, a także $z$ bogactwa form życia religijnego, specyfiki przeżyć $i$ aktów religijnych, które jako akty osoby, a nie natury, są niepowtarzalne ${ }^{17}$. $Z$ tych też powodów zjawisko religii jest wyjaśniane w bardzo różnych aspektach ${ }^{18}$. Można je łączyć z całokształtem wydarzeń, za pośrednictwem których ludzie wyrażają swe przekonania o bezwarunkowej skończoności

15 K. Rahner, H. Vorgrimler, Maty stownik teologiczny, tłum. T. Mieszkowski, P. Pachciarek, Warszawa 1987, s. 387; U. Berner, Religia, w: Leksykon religii, red. F. König, H. Waldenfels, tłum. P. Pachciarek, Warszawa 1997, s. 392.

16 U. Berner, Religia, dz. cyt., s. 392. Por.: E. Sakowicz, Religioznawstwo, Lublin 2009, s. 10; Z. Zdybicka, Transcendentne odniesienie cztowieka, dz. cyt., s. 71; J. Michalski, Edukacja i religia jako źródto rozwoju egzystencjalno-kognitywnego. Studium hermeneutyczno-krytyczne, Torun 2004, s. 107.

17 Z. Zdybicka, Transcendentne odniesienie cztowieka, dz. cyt., s. 71-73.

18 Por. M.M. Boużyk, Wychowanie otwarte na religię. Polska Szkota Filozofii Klasycznej o roli religii w wychowaniu, Warszawa 2013, s. 124-140. 
swojej egzystencji i niemożności jej przezwyciężenia ${ }^{19}$, albo też z uznaniem osobowego podmiotu, w którym człowiek poszukuje genezy i sensu swego życia. Poszukiwania te związane są z jego świadomym zwracaniem się do Kogoś - osoby, a nie do czegoś - rzeczy. Wiąże się to z uznawaniem własnej ograniczoności, a to umożliwia stawianie pytań o charakterze religijnym, na które można otrzymać przynajmniej częściowo odpowiedź dzięki wiedzy religijnej ${ }^{20}$. Jej brak sprzyja bowiem budowaniu religijności, która posiada charakter magiczny i niewiele ma wspólnego dojrzałą wiarą (chrześcijańską).

Badania fenomenu religii prowadzone przez polskich filozofów określają religię jako „realną i dynamiczną relacją osobową człowieka do osobowego Absolutu, od którego człowiek jest zależny w istnieniu oraz działaniu i który jest jego ostatecznym celem, nadającym sens jego życiu” ${ }^{21}$. W definicji tej zwraca się uwagę na to, że człowiek żyjąc w układzie horyzontalnym odkrywa własną ograniczoność, niemożność spełnienia siebie - swych dążeń i pragnien. Uświadamiana ograniczoność doprowadza go „do punktu granicznego, napiętnowanego gehenną cierpienia, bezdenną czeluścią, która zionie traumatyczną, porażającą grozą śmierci, pustką bezsensu i unicestwienia" - zauważa Mieczysław Rusecki. Jego zdaniem, człowiek w obliczu tego doświadczenia dostrzega, że droga ta prowadzi donikąd i że sam nie jest w stanie jej zmienić. Uświadamia sobie, że sensownej zmiany tej sytuacji może dokonać ,jedynie transcendentne «Ty» w Osobie tego, który świadomie i dobrowolnie wszedł w nasz los, poddał się cierpieniu, przekroczył granice śmierci i pojawił się na nowo wśród żyjących”. Doświadcza przy tym, że nie przestrzeń życia horyzontalnego, a wertykalnego umożliwia mu zmianę egzystencjalnej sytuacji. Zdaniem M. Ruseckiego, właśnie „ta relacja oznacza «być albo nie być» dla człowieka. Stanowi rzeczywiste otwarcie na całe pole bytu [...], na Prawdę Absolutną i na wszelkie dobro - aż po Dobro Absolutne (Boga)"22. Sytuacja ta pokazuje, że zdobywane w ciągu życia

19 J. Michalski, Edukacja i religia jako źródto rozwoju egzystencjalno-kognitywnego, dz. cyt., s. 111.

20 R. Goldman, Vorfelder des Glaubens, Neukirchen 1972, s. 50.

21 M.M. Boużyk, Wychowanie otwarte na religie, dz. cyt., s. 134.

22 M. Rusecki, Wychowanie religijne w rodzinie, w: Religijno-moralny wymiar rozwoju $i$ wychowania, red. A. Rynio, K. Braun, A. Lendzion, D. Opozda, Lublin 2012, s. 302; por. R. Goldman, Vorfelder des Glaubens, dz. cyt., s. 57. 
doświadczenia ukierunkowują człowieka wertykalnie i umożliwiają mu wychodzenie poza własną ograniczoność oraz zwracanie się ku Transcendencji. Stąd też doświadczanie własnej ograniczoności oraz wysiłek jej przekraczania pozwalają człowiekowi uznać Transcendencję - Boga i nawiązywać z Nim osobowe relacje. Wynika z tego i to, że wiara w Boga w pierwszej kolejności nie jest oparta na uczuciach, lecz na rozumie i decyzjach woli człowieka. Bez ich udziału byłaby ona nieodporna na przeciwności i trudności, które mogłyby ją łamać23.

W refleksji nad istotą religii należy zwracać uwagę także na to, co różni poszczególne religie. Chodzi przede wszystkim o objaśnianie istoty i natury Transcendencji - Boga. W jednych religiach jest On bytem osobowym, a w innych nieosobowym; może być duchowym lub materialnym; może posiadać wymiar moralny albo być jakąś techniczną siłą ${ }^{24}$. Różnice doktrynalne, jakie zachodzą między religiami, dotyczą też odpowiedzi na kluczowe dla człowieka pytania o jego egzystencję ${ }^{25}$.

Człowiek żyjący w kręgu kultury europejskiej winien mieć też świadomość, że wyrasta ona z chrześcijaństwa. Jej właściwością jest kierowanie „ku górze”, ku życiu wiecznemu, które ofiaruje ludziom żywy Bóg. Znajomość chrześcijaństwa jest więc kluczem do zrozumienia kultury europejskiej. Chrześcijaństwo uważa się za religię objawioną. Czynnikiem odróżniającym je od każdej innej religii jest wiara w osobowego, Trójjedynego Boga, który jest Bogiem jedynym, chociaż istnieje w trzech osobach, jako Ojciec, Syn i Duch Święty. Rzeczywistość ta jest ścisłą tajemnicą wiary, której człowiek nie jest w stanie zrozumieć za pomocą swego intelektu ${ }^{26}$. Za pośrednictwem religii chrześcijańskiej Bóg daje ludziom poznać siebie i swoje wobec nich zamiary. Chrześcijaństwo podkreśla przy tym, że Bóg pozostawia im wolność, bo chce by dobrowolnie Go wybierali. Te skrótowe objaśnienia odnoszące się do istoty religii pozwalają wnioskować, co religia, jeśli zostaje przyjęta przez człowieka, wnosi w jego

23 W. Cichosz, Pedagogia wiary we wspótczesnej szkole katolickiej, Warszawa 2010, s. 151.

24 Z. Zdybicka, Transcendentne odniesienie cztowieka, dz. cyt., s. 73.

25 Por. S. Zięba, Cztowiek. 2. Pochodzenie, w: Leksykon pedagogiki religii, red. C. Rogowski, Warszawa 2007, s. 93-99.

26 Por.: Katechizm Kościota katolickiego, Poznań 1994, nr 233, 234, 237; K. Rahner, H. Vorgrimler, Trójca Święta, w: Maty stownik teologiczny, dz. cyt., s. 501-503. 
życie. Do ważniejszych elementów można zaliczyć poczucie bezpieczeństwa, którego gwarantem jest osobowy Bóg. Jego bliskość (w chrześcijańskim rozumieniu) umożliwia człowiekowi odkrywanie głębszego sensu własnej egzystencji, a także przeznaczenia do życia pozbawionego lęku, zagrożeń, a przeżywanego w miłości i przez całą wieczność.

\section{Wkład religii chrześcijańskiej w rozumienie człowieka}

Religia umożliwia człowiekowi nawiązanie relacji „z transcendencją, rzeczywistością sakralną (nazywaną tajemnicą, bóstwem, czymś wyższym, Bogiem), uznaje jej realną obecność i udziela jej odpowiedzi na wezwanie, słowa, miłość $\mathrm{z}$ pełnym zaangażowaniem swych władz poznawczych i wolitywno-emocjonalnych, mając nadzieję na osiągnięcie ostatecznego swego celu, szczytu bytowości" - Transcendencji, samego Boga ${ }^{27}$. W tym rozumieniu rozwój biologiczny nie wyczerpuje zjawiska dynamizmu, który tkwi w człowieku. Sytuacja ta domaga się wyjaśnienia i skonstruowania obrazu człowieka, po to, by wyjaśnić jego byt ${ }^{28}$. Naprzeciw tym oczekiwaniom wychodzą systemy filozoficzne oraz oparte na nich antropologie. Każda z nich podaje określoną koncepcję poznania, działania, a także etyki i aksjologii ${ }^{29}$. W tym miejscu zatrzymamy się jedynie na objaśnieniach natury człowieka podawanych przez filozofię i teologię chrześcijańską.

27 Por.: L.F. Ladaria, Wprowadzenie do antropologii teologicznej, tłum. A. Baron, Kraków 2002, s. 14-15; A. Gałdowa, A. Nelicki, O możliwościach i warunkach bycia twórczym z perspektywy aksjologicznej teorii wartości, „Zeszyty Naukowe Uniwersytetu Jagiellońskiego. Prace Psychologiczne” 1993, z. 8, s. 7-28.

28 K. Bochenek, Kategoria życia osobowego fundamentem wychowania, w: Dzisiejszy katechizorwany. Stan aktualny i wyzwania, red. J. Stala, Kraków 2002, s. 54.

29 J. Horowski, Wychowanie moralne wedtug pedagogiki neotomistycznej, Toruń 2015, s. 18; por. M. Jeziorański, Wychowawcza wartośc wspólnoty w odniesieniu do wybranych koncepcji antropologicznych, „Acta Universitatis Nicolai Copernici. Nauki Humanistyczno-Społeczne. Pedagogika” 2014, z. 422, s. $27-47$. 


\section{Natura człowieka}

W literaturze znajdziemy różne wyjaśnienia natury człowieka ${ }^{30}$. Ich autorzy odwołują się zarówno do filozofii monistycznej, jak też dualistycznej ${ }^{31}$. Do zwolenników pierwszego nurtu należy zaliczyć przedstawicieli skrajnego materializmu. Uważają oni, że człowiek jest tylko bytem cielesnym. Zajmując takie stanowisko, nie jesteśmy w stanie wyjaśnić istoty człowieka, między innymi dlatego, że nauki przyrodnicze, badające rzeczywistość materialną, są bezradne wobec wielu pytań dotyczących człowieka. $Z$ tego powodu nie udzielają odpowiedzi na pytanie o to, czy istnieje dusza (duch), czy tylko materia; czy istnieje wolność, czy raczej w świecie panuje determinizm; czy istnieje celowość, czy tylko przypadek; czy istnieją wartości, czy jedynie proste fakty? Próby rozstrzygania tych kwestii przez nauki przyrodnicze są nieosiągalne dlatego, że musiałyby one przekroczyć dostępny dla nich zakres badań. Wobec pojawiających się ograniczeń nauk przyrodniczych odpowiedź na pytanie: kim jest człowiek, jakim jest świat, w którym on żyje, może zostać udzielona jedynie na gruncie filozoficzno-religijnym ${ }^{32}$.

$\mathrm{Z}$ kolei przedstawiciele dualizmu, akceptując istnienie w człowieku pierwiastka materialnego, jak i duchowego, przyjmują, że człowiek składa się z substancji cielesnej - materialnej i duchowej - niematerialnej. Dyskutują jednak nad relacjami, w jakich pozostają wobec siebie oba te pierwiastki. $\mathrm{W}$ ich rozumieniu albo jeden, albo drugi posiada pozycję nadrzędną w stosunku do drugiego. Dane empiryczne prowadzą do odrzucenia zarówno skrajnych stanowisk monistycznych, jak i dualistycznych. Skłania ku temu przekonanie, że

człowiek jest ścisłą (co najmniej funkcjonalnie) jednością elementów i czynników różnorodnych, paradoksalnym wręcz splotem psychiczności

30 Por.: W. Szewczyk, Kim jest cztowiek. Zarys antropologii fllozoficznej, Tarnów 1994; T. Ślipko, Zarys etyki ogólnej, Kraków 2002, s. 51-54; S. Jasionek, Uprawnienia i zobowiqzania cztowieka, Częstochowa 1999, s. 37-42. S. Jasionek, Uprawnienia i zobowiazania cztowieka, dz. cyt., s. 39.

31 Por.: W. Szewczyk, Kim jest człowiek, dz. cyt.; T. Ślipko, Zarys etyki ogólnej, dz. cyt., s. 51-54; S. Jasionek, Uprawnienia i zobowiazania cztowieka, dz. cyt., s. $37-42$.

32 J. Horowski, Wychowanie moralne wedtug pedagogiki neotomistycznej, dz. cyt., s. 201. 
i cielesności, świadomości i nieświadomości, indywidualności i wspólnotowości (a także indywidualności opozycji), transcendującym w rozmaity sposób to, co w nim immanentne ${ }^{33}$.

Te biegunowo przeciwstawne objaśnienia wskazują, że aktualnie nie dysponujemy jednorodnymi narzędziami, które pozwoliłyby jednoznacznie wyjaśnić naturę człowieka ${ }^{34}$.

Naturę człowieka wyjaśniają też chrześcijańska filozofia oraz teologia. Nauki te określają człowieka mianem istoty cielesno-duchowej. Podkreślają w ten sposób nierozłączność jego ducha i ciała oraz idących w parze z tym przymiotów wewnętrzności i zewnętrzności ${ }^{35}$. W nauczaniu Kościoła katolickiego istniejąca ,jedność ciała i duszy jest tak głęboka, że można uważać duszę za «formę» ciała; oznacza to, że dzięki duszy duchowej ciało utworzone $z$ materii jest ciałem żywym i ludzkim; duch i materia w człowieku nie są dwiema połączonymi naturami, ale ich zjednoczenie tworzy jedną naturę" ${ }^{36}$. Jedność ta zakłada nierozłączność: zewnętrzność (ciało) i wewnętrzność (dusza) są z sobą ściśle powiązane. Dusza jest uposażona w takie przymioty, jak wolności i rozumność, dzięki którym człowiek może decydować o sobie: „kim chce być”. Może kierować sobą. Zdolność ta umożliwia mu rządzenie sobą, a także kształtowanie i rozwijanie własnej osobowości ${ }^{37}$. To z kolei czyni go zdolnym do wykraczania poza granice zdeterminowania narzucanego przez materię i wyrażenia swych dążeń do niezdeterminowania. Wynika z tego, że człowiek jest bytem substancjalnym (nie tylko wiązką aktów świadomościowych), a w jego strukturze występują dwie konstytutywne zasady, nawzajem do siebie ostatecznie niesprowadzalne. Pierwsza jest pierwiastkiem materialnym (ciało), a druga pierwiastkiem duchowym

33 Por. K. Ablewicz, (Nie)obecnośc ducha w wychowaniu cztowieka. Z filozofii kultury Bogdana Nawroczyńskiego, „Horyzonty Wychowania” 2007, t. 6, nr 11, s. 58.

34 Por.: Z. Chlewiński, A. Stanowski, Cztowiek - interpretacja scjentystyczno-kulturowa, w: Encyklopedia katolicka, t. 3, red. R. Łukaszyk, L. Bieńkowski, F. Gryglewicz, Lublin 1979, kol. 910-914; W. Szewczyk, Kim jest człowiek, dz. cyt.

35 B. Sesboüé, Wierzę. Wezwanie do wiary katolickiej dla kobiet i mężczyzn XXI wieku, tłum. M. Żurowska, Warszawa - Poznań 2000, s. 350.

36 Katechizm Kościota katolickiego, nr 365 (Dalej w skrócie: KKK).

37 P. Góralczyk, Wychowawcza etyka seksualna, Ząbki 2000, s. 12. 
(dusza nieśmiertelna). Obie są jednakowo realne. Obie pozostają w relacji, stają się elementarnymi składowymi częściami jednej (czyli wewnętrznie jednolitej) natury człowieka ${ }^{38}$, co oznacza, że jego zewnętrzność i wewnętrzność zawsze idą w parze ${ }^{39}$. To zaś sprawia, że mówimy o żywym ludzkim ciele ${ }^{40}$.

$\mathrm{Za}$ uposażeniem natury człowieka $\mathrm{w}$ zarówno $\mathrm{w}$ pierwiastek materialny, jak i niematerialny przemawia ogniskowanie się „w jednej jaźni zarówno aktów fizjologicznych, jak i aktów psychiczno-duchowych"41. Stąd też istniejąca w nim jedność ciała i ducha sprawia, że zarówno jego ciało, jak i duch pozostają do siebie we wzajemnej, chociaż niesprowadzalnej relacji; stanowią elementarne części składowe jednej (czyli wewnętrznie jednolitej) natury. Oznacza to, że człowiek pozostając bytem fizycznym, osobowym, jest skierowany ku jeszcze innym stopniom doskonałości urzeczywistnianej mocą jego działania ${ }^{42}$. Hans-Georg Ziebertz i Stefan Heil dostrzegają w naturze człowieka trzy istotne sfery: cielesną, umysłową i duchową, ściśle z sobą związane, co jest podstawowym uposażeniem każdego człowieka. Tłumaczą, że określenie „cielesny” jest synonimem tego, co materialne. W odróżnieniu od pojęcia materii, które uważają za pojęcie uniwersalne, cielesność stanowi indywidualną właściwość każdego człowieka. $Z$ kolei termin „umysłowy" odnoszą do kognitywnych i emocjonalnych struktur ludzkiej natury. Podkreślają, że częste przywoływanie cielesności ludzkiej natury ma uwypuklić znaczenie indywidualnej i psychicznej konstytucji człowieka. Trzecią sferę, nadającą kształt ludzkiej naturze, łączą z duchowym wymiarem ludzkiego życia. Uważają, że sfery tej nie można wyjaśnić w kategoriach ciała i umysłu. Dlatego jakościowo odróżniają ją od kategorii ciała i umysłu. Tłumaczą, że duchowy obszar ludzkiego życia wyraża zdolność do ponoszenia odpowiedzialności za posiadaną wolność. Te właściwości wpisują w pozostałe sfery jego natury, tłumacząc, że zarówno sfera duchowa, jak

38 T. Ślipko, Zarys etyki ogólnej, dz. cyt., s. 51.

39 B. Sesboüé, Wierzę. Wezwanie do wiary katolickiej dla kobiet i mężczyzn XXI wieku, dz. cyt., s. 350.

40 KKK, nr 365.

${ }_{41}$ B. Sesboüé, Wierzę. Wezwanie do wiary katolickiej dla kobiet i mężczyzn XXI wieku, dz. cyt., s. 350.

42 T. Ślipko, Zarys etyki ogólnej, dz. cyt., s. 222. 
też cielesna oraz umysłowa posiadają cechy indywidualne i zawsze towarzyszą każdej życiowej decyzji ${ }^{43}$.

Oprócz ciała cielesno-duchowa natura człowieka eksponuje też ducha (duszę). W chrześcijańskim rozumieniu „duch” („dusza”) wyraża sedno osobowości człowieka i jego podmiotowośćc ${ }^{4}$. Posiada on trzy konteksty znaczeniowe. Jest pierwiastkiem ożywianej, jednoczącej i porządkującej rzeczywistości; rodzajem substancji, która występuje w dwóch odmianach: zdolnego do świadomości bytu osobowego oraz wartości kulturowej; podmiotem lub elementem psychiki. Pierwiastek ten definiuje umysł, duszę, myślenie, intelekt z jednej strony, a z drugiej - wewnętrzną energię psychiczną, wyrażaną ludzką mocą, siłą, męstwem czy odwagą ${ }^{45}$. Dzięki tym właściwościom

człowiek przerasta swoją głębią całą rzeczywistość materialną. Powraca do tej niezmierzonej głębi, gdy zwraca się ku sercu, gdzie oczekuje na niego Bóg, który bada serca, gdzie sam w oczach Boga decyduje o swoim losie. Dlatego, uznając w sobie istnienie duszy niematerialnej i nieśmiertelnej, nie poddaje się zwodniczemu złudzeniu wypływającemu jedynie z przesłanek materialnych i społecznych, lecz przeciwnie - dociera właśnie do głębi prawdy o rzeczywistości ${ }^{46}$.

W literaturze przedmiotu można napotkać rozróżnienie między duchem i duszą. Rozróżnienie to nie wprowadza żadnego dualizmu duszy. Biblia terminem „duch” (dusza) wyraża życie człowieka - całą jego osobę - ożywioną „duchem” życia. Pojęcie to wyraża wszystko, co jest w człowieku najbardziej wewnętrzne i najwartościowsze; wszystko, co sprawia, że staje się on obrazem Boga. Dzięki duszy duchowej ciało utworzone z materii jest ciałem żywym i ludzkim, które dąży do osiągnięcia ostatecznego celu życia ${ }^{47}$. Istotna jest przy tym wiara chrześcijan, że w chwili oddzielenia duszy od ciała - w chwili śmierci człowieka - dusza nie ginie. Co więcej, wraz z ostatecznym

43 H.-G. Ziebertz, S. Heil, Antropologiczne podstawy ksztatcenia religijnego, „Horyzonty Wychowania” 2002, t. 1, nr 1, s. 131-132.

44 S. Jasionek, Uprawnienia i zobowiqzania cztowieka, dz. cyt., s. 39.

45 K. Ablewicz, (Nie)obecnośc ducha w wychowaniu cztowieka, dz. cyt., s. 57.

46 Sobór Watykański II, Konstytucja duszpasterska o Kościele w śrwiecie wspótczesnym, w: Sobór Watykański II, Konstytucje, dekrety, deklaracje, Poznań 2002, nr 14 (Dalej w skrócie: KDK).

47 Sobór Watykański II, Deklaracja o wychowaniu chrześcijańskim, w: Sobór Watykański II, Konstytucje, dekrety, deklaracje, Poznań 2002, nr 1. 
zmartwychwstaniem ponownie połączy się z ciałem. Na tej drodze chrześcijaństwo objaśnia pochodzenie i przeznaczenie człowieka, który od chwili stworzenia zmierza ku wyznaczonemu mu nadprzyrodzonemu celowi - życiu z Bogiem ${ }^{48}$. Tak więc duch oznacza „zasadę duchową" dającą ludzkiemu ciału życie, tworząc w ten sposób istotę zwaną człowiekiem. Dusza uzdalnia do tego, by w darmowy sposób kierować człowieka ku Bogu ${ }^{49}$. Zatem ma ona realny związek z ludzkim ciałem, gdyż człowiek jest bytem żywym i rozumnym, tożsamym $z$ sobą i niepodzielnym zarówno w wymiarze życia biologicznego (życia wegetatywnego), popędowo-zmysłowego, jak i osobowego ${ }^{50}$. W antropologii chrześcijańskiej podkreśla się, że ciało służy duszy, ale nie jest jej narzędziem w sensie „rzeczy”. Natomiast ich jedność czyni człowieka podmiotem działania ${ }^{51}$ dzięki zdolności do poznania zarówno siebie, jak i swego otoczenia oraz przekraczania granic własnej niemożności.

\section{Cztowiek osobq}

Na gruncie refleksji religijnej (chrześcijańskiej) nad „innością” natury człowieka wyrósł nurt nazwany personalizmem. Jego podstaw należy doszukiwać się w prowadzonych $\mathrm{w}$ drugiej połowie XIX i na początku XX wieku badaniach nad naturą człowieka. Ich inicjatorami byli chrześcijańscy filozofowie: Jacques Maritain, Emmanuel Mounier, Max Scheler, Pierre Teilhard de Chardin. Do tego grona chrześcijańskich myślicieli zalicza się też Karola Wojtyłę, Wincentego Granata, Czesława Stanisława Bartnika ${ }^{52}$. Myśliciele ci podkreśla-

48 Por. T. Kot, Duch w Biblii, „Horyzonty Wychowania”2007, t. 6, nr 11, s. 81-90.

49 Por. KKK, nr 362-368.

50 B. Kiereś, Podstawy antropologiczne pedagogiki personalistycznej, w: Antropologiczna pedagogika ogólna, red. M. Nowak, P. Magier, I. Szewczak, Lublin 2010, s. 96.

51 Por. A. Zoll, Cztowiek jako podmiot wolności i praw w jednoczacej się Europie, w: Cztowiek w jednoczacej się Europie, red. A. Królikowska, Kraków 2004, s. $45-56$.

52 Por.: W. Granat, Personalizm chrześcijański. Teologia osoby ludzkiej, Poznań 1985; J. Czarkowski, Oblicza personalizmów. Konfrontacja antropologii filozoficznej E. Mouniera i P. Teilharda de Chardin, Torun 1994; K. Wojtyła, Osoba i czyn, Lublin 1994; C. Bartnik, Personalizm, Lublin 1995; Wychowanie personalistyczne. Wybór tekstów, red. F. Adamski, Kraków 2005. 
li samodzielne istnienie człowieka oraz jego odrębność i niezależność od innych bytów. Założenie to stało się podstawą do promowania pojęcia „osoba” ${ }^{3}$. Wyraża ono konkretny, ze swej natury samoistny i realnie istniejący byt, a nie jakąś abstrakcję. Byt ten staje się „zasadą" zdolną do określonego działania, naznaczonego aktami poznania, wolności i odpowiedzialności. Za ich pośrednictwem wyraża swą wewnętrzną i duchową wolność, której osiąganie staje się podstawowym obowiązkiem człowieka ${ }^{54}$. Co więcej, uposażenie w cechy duchowe wyzwala w osobie dążenia do przekraczania siebie i kierowania się ku transcendencji, niezależnie od tego, jak jest ona rozumiana. Właściwości te sprzyjają nawiązywaniu relacji międzyosobowych, które łączą osobę z naturą, kulturą i transcendencją i umożliwiają pełniejsze poznanie istoty człowieczeństwa ${ }^{55}$.

Pojęciu „osoba” w ciągu dziejów nadawano różne znaczenia ${ }^{56}$. Współcześnie często przywoływana jest definicja Boecjusza ${ }^{57}$, który osobę określił mianem „poszczególnej substancji natury rozumnej” (tłumaczenie T. Jachimowskiego) albo ,jednostkowej substancji natury rozumnej" (tłumaczenie W. Granata). Zdaniem Zbigniewa Teinerta, definicja ta łączy dwa elementy: indywidualizację osoby oraz jej rozumność, chociaż nie wyjaśnia, kim jest osoba. W jego rozumieniu najbardziej realistyczne wyjaśnienia istoty osoby podał św. Tomasz z Akwinu. Łączył on augustyńską ideę prawa wiecznego (lex aeterna - Bóg jako źródło i zasada wszystkich praw) z koncepcją prawa naturalnego (lex naturalis). Osobę charakteryzuje świadome działanie oparte na poznaniu, wolności i odpowiedzialności. Zdolność do takiego działania sprawia, że człowiek potrafi sobą kierować, ustanawiać ciągłość między przeszłością, czasem obecnym i przyszłością, zarówno w najbardziej banalnych wyborach, jak i bohaterskich decyzjach. To zaś pociagga za

53 Szerzej: M. Nowak, Teorie i koncepcje wychowania, Warszawa 2008, s. 155165.

54 J. Horowski, Wychowanie moralne wedtug pedagogiki neotomistycznej, dz. cyt., 205-206.

55 M. Nowak, Pedagogika personalistyczna, w: Pedagogika, red. Z. Kwieciński, B. Śliwerski, Warszawa 2005, s. 242.

56 Por.: Z. Teinert, Osoba, w: Leksykon pedagogiki religii, dz. cyt., s. 494-498; Osoba, w: Praktyczny stownik biblijny, red. A. Grabner-Haider, tłum. T. Mieszkowski, P. Pachciarek, Warszawa 1994, s. 907.

57 Por. M.A. Krąpiec, Cztowiek - dramat natury i osoby, w: Wychowanie personalistyczne. Wybór tekstów, red. F. Adamski, Kraków 2005, s. 31. 
sobą właściwe tylko osobie konsekwencje nazywane moralnością bądź życiem moralnym ${ }^{58}$. Na tej drodze człowiek odkrywa, że na świecie nie jest sam, że wespół z nim żyją także inne osoby. Odkrycie to inspiruje go do poszukiwania możliwości nawiązania $\mathrm{z}$ nimi kontaktu, a także wzbudza pragnienie takiego zarządzania rzeczami, by służyły wspólnemu dobru. Podobnie rzecz się ma w jego dążeniach do prawdy i dobra. Charakteryzuje je kierowanie się nie tyle własnym interesem, co dobrem innych. Te same odczucia towarzyszą spełnianiu powinności, które pozostając w ścisłym związku $\mathrm{z}$ wolnością chronią osobę przed nieuprawnioną ingerencją z zewnątrz. Dzięki temu człowiek jako osoba potrafi nie tylko dostrzegać, ale nade wszystko w sposób wolny akceptować obowiązujące normy życia społecznego ${ }^{59}$.

Treści wpisane w pojęcie osoby doprowadziły do wypracowania systemu filozoficzno-społeczno-teologicznego, który nazwano personalizmem $^{60}$. Nazwa ta wywodzi się z lacińskiego słowa persona i oznacza „ogląd, poznanie i doświadczenie rzeczywistości z perspektywy osoby, a następnie budowanie świata bardziej ludzkiego" ${ }^{1}$. Cechą odróżniającą personalizm od naturalizmu czy kulturalizmu jest podejście do sfery bumanum, skutkujące redefinicją podstawowych pytań antropologicznych. W przekonaniu Romana Schulza personalizm koncentruje swoją uwage na wymiarze indywidualnym bytu ludzkiego. Ukazuje go w kategoriach przedmiotowość-podmiotowość. Eksponując te właściwości, ukazuje, że człowiek jest indywiduum, osobą, świadomym siebie podmiotem, istotą samookreślającą się, wewnątrzsterowną, tworzącą samą siebie $^{62}$. Przez eksponowanie tych cech

58 P. Góralczyk, Wychowawcza etyka seksualna, dz. cyt., s. 12.

59 Z. Teinert, Osoba, w: Leksykon pedagogiki religii, dz. cyt., s. 497; por. M.A. Krąpiec, Cztowiek bytem osobowym, w: Wychowanie na rozdrożu. Personalistyczna filozofia wychowana, red. F. Adamski, Kraków 1999, s. 81-83.

60 Por.: F. Adamski, Wprowadzenie: Personalizm - filozoficzny nurt myślenia o cztowieku $i$ wychowaniu, w: Wychowanie personalistyczne. Wybór tekstów, red. F. Adamski, Kraków 2005, s. 9; W. Cichosz, Wychowanie chrześcijańskie wobec postmodernistycznej prowokacji, Gdańsk 2001, s. 101-117; M. Nowak, Teorie i koncepcje wychowania, Warszawa 2008, s. 159-160.

61 D. Theil-Bielańska, Osoba jako podmiot wychowania w świetle koncepcji personalizmu integralnego ks. Wicentego Granata, w: Chrześcijanskie inspiracje w pedagogice, red. J. Kostkiewicz, Kraków 2011, s. 80.

62 Por. A. Zoll, Cztowiek jako podmiot wolności i praw w jednoczacej się Europie, dz. cyt., s. 45-56. 
personalizm przyjmuje na ogół, w wielorakości swoich ujęć, postawę otwarcia na egzystencję, ujmowaną w wymiarze przestrzenno-czasowym. Zdaje się także bardzo wyraźnie eksponować wątek porzucenia statycznej koncepcji „osoby” (a zatem swoiste odejście od metafizyki klasycznej) i poszukiwanie żywych, zanurzonych w egzystencję determinantów życia osobowego ${ }^{63}$.

Personalizm jako system filozoficzno-społeczno-teologiczny znalazł wielu zwolenników. Pośród nich są także pedagodzy chrześcijańscy. W nim znaleźli ontologiczno-aksjologiczne podstawy koncepcji człowieka jako osoby. Jego odrębność od innych systemów polega na tym, że postrzega człowieka jako podmiot każdego działania uzdalniającego do tworzenia harmonii w życiu społecznym ${ }^{64}$. Człowiek jako osoba przyczynia się również do wyzbywania się chęci skupiania uwagi na sobie samym oraz eksponowania działań skierowanych na dobro innych ${ }^{65}$. Umożliwia przekraczanie własnej ograniczoności. Zdolność ta potwierdza zarówno osobową tożsamość człowieka, jak też boski wymiar człowieczeństwa ${ }^{66}$, którego pełnię odsłania Jezus Chrystus swoją obecnością w ludzkiej historii. To połączenie rzeczywistości naturalnej z nadprzyrodzoną spowodowało wyzwolenie natury ludzkiej z ograniczoności oraz obdarowanie jej nieśmiertelnością ${ }^{67}$.

Przedstawiciele personalizmu chrześcijańskiego eksponują potrzebę „porzucenia statycznej koncepcji «osoby» (a zatem swoiste odejście od metafizyki klasycznej) i poszukiwanie żywych, zanurzonych w egzystencję determinantów życia osobowego" ${ }^{\prime 68}$. Ujęcie to pro-

63 M. Nowak, Pedagogika personalistyczna, dz. cyt., s. 232.

64 Por. A. Zoll, Cztowiek jako podmiot wolności i praw w jednoczacej sie Europie, dz. cyt., s. 45-56.

65 Por.: J. Bagrowicz, Wychowanie cztowieka jako osoby w świetle pedagogiki chrześcijańskiej, dz. cyt., s. 48-63; F. Adamski, Personalistyczna wizja cztowieka $i$ kultury u podstaw wychowania chrześcijańskiego, dz. cyt., s. 64-70; M. Śnieżyński, Dialog edukacyjny, Kraków 2001, s. 45-49; B. Kiereś, Podstawy antropologiczne pedagogiki personalistycznej, dz. cyt., s. 95-102.

66 P. Kazimierczak, Personalistyczna koncepcja wychowania w nauczaniu Jana Pawta II, Kraków 2003, s. 23.

67 R. Niparko, Wychowanie religijne jako wychowanie humanistyczne-perspektywa personalistyczna, „Paedagogia Christiana” 2003, nr 2(12), s. 19; por. W. Cichosz, Możliwości dialogu wychowania chrześcijańskiego ze wspótczesna edukacja polska, Pelplin 2013, s. 108-109.

68 M. Nowak, Pedagogika personalistyczna, dz. cyt., s. 232. 
muje rozumienie natury człowieka określanej jako „byt pochodny”. Chodzi o postrzeganie człowieka jako osobę, która otrzymała istnienie-życie bez pośrednictwa natury; jego osobowe istnienie (istnienie jako człowieka) nie jest następstwem działań natury ${ }^{69}$, lecz Boga nieskończonego Bytu, który jest też ostatecznym źródłem każdego innego bytu. Wynika $z$ tego, że człowiek ze swej istoty jest bytem całkowicie podporządkowanym Bogu i do Niego skierowanym. Od Boga otrzymuje też niezbędną pomoc w samorealizacji i osiąganiu pełni człowieczeństwa poprzez poszerzanie posiadanej wiedzy, umiejętności właściwego rozsądzania oraz rozwój cnót moralnych i otwarcie na wartości kultury ${ }^{70}$. Personalizm chrześcijański potwierdza więc możliwość wychodzenia człowieka poza własną ograniczoność, a nadto wskazuje, jak człowiek może przekraczać tę granicę. Zdolność zwracania się w kierunku tego, co „nieskończone”, ,absolutne” ku Bogu, powoduje wyłamywanie się ze skończoności i otwarcie na nieskończoność: na to, co absolutne i co religijne; na to, co stanowi sacrum - Transcendencję ${ }^{71}$. Działaniami tymi człowiek potwierdza własną tożsamość oraz boski wymiar swego człowieczeństwa ${ }^{72}$, którego pełnię odsłania przed nim Jezus Chrystus ${ }^{73}$. Konsekwentnie możemy przyjąć, że popularność personalizmu chrześcijańskiego bierze się stąd, iż promuje on autonomiczną wartość człowieka jako osoby stworzonej przez Boga i powołanej do życia z Nim przez całą wieczność ${ }^{74}$.

69 M.A. Krąpiec, Cztowiek - dramat natury i osoby, dz. cyt., 38; por. S. Kowalczyk, R. Krajewski, Osoba, w: Encyklopedia katolicka, t. 14, red. E. Gigilewicz, Lublin 2010, kol. 903.

70 Por. S.C. Michałowski, Pedagogia personalistyczna wsparciem ksztattujacego się systemu wychowania u początków XXI wieku, w: Nowe konteksty (dla) edukacji alternatywnej XXI wieku, Kraków 2001, s. 643.

71 Por.: H.-G. Ziebertz, S. Heil, Antropologische Grundlage Religioesen Lernens, „Horyzonty Wychowania” 2002, t. 1, nr 1, s. 113-115; S. Jasionek, Uprawnienia i zobowiqzania cztowieka, dz. cyt., s. 41-42.

72 P. Kazimierczak, Personalistyczna koncepcja wychowania w nauczaniu Jana Pawta II, dz. cyt., s. 23.

73 R. Niparko, Wychowanie religijne jako wychowanie humanistyczne - perspektywa personalistyczna, dz. cyt., s. 19; por. W. Cichosz, Możliwości dialogu wychowania chrześcijańskiego ze wspótczesnq edukacja polskq, dz. cyt., s. 108-109.

74 W. Cichosz, Wychowanie chrześcijańskie wobec postmodernistycznej prowokacji, dz. cyt., s. 121-151. 


\section{Godność człowieka}

Wypracowana przez filozofię i teologię chrześcijańską antropologia stawia człowieka na najwyższym stopniu hierarchii istnień świata biologicznego. Decyduje o tym jego inteligencja uzdalniająca do wykraczania poza granice świata ożywionego ${ }^{75}$. Doświadczenie własnej ograniczoności, a jednocześnie dążenie do wychodzenia poza jej granice, uświadamia człowiekowi, że jedynie Transcendencja (Bóg) może mu podać sensowne wyjaśnienie jego życiowej sytuacji ${ }^{76}$. Na tej drodze dochodzi do nobilitacji ludzkiej natury. Zdolność do tego, by pozostając fizycznym bytem osobowym, stawać się bytem „ponadfizycznym", umożliwia osobie odkrywanie posiadanej godności. W tym trudzie pomocna dla człowieka jest religia, której nie można identyfikować $\mathrm{z}$ etyką, a tym bardziej z moralnością, nawet wówczas, gdy religię będzie się usiłować uczynić narzędziem moralizującym ${ }^{77}$. Ona wskazuje kierunek stawania się innym, coraz doskonalszym bytem $^{78}$, zdolnym do wychodzenia poza własną ograniczoność i poszukiwania dobra nieprzemijającego, trwałego, wiecznego ${ }^{79}$. Właściwości te umożliwiają człowiekowi uświadomienie sobie własnej odrębności w stosunku do każdego innego istnienia. Zdolność tę nazywamy godnością.

Godność jest wpisana w naturę każdego człowieka. Wyraża afirmację osoby oraz wszystko, co ją odróżnia od pozostałych istnień; co powoduje, że staje się ona ośrodkiem życia świata ${ }^{80}$. W odkrywaniu posiadanej godności przychodzi człowiekowi z pomocą zarówno

75 Por. A. Krąpiec, Cztowiek - interpretacja filozoficzna, w: Encyklopedia katolicka, t. 3, red. R. Łukaszyk, L. Bieńkowski, F. Gryglewicz, Lublin 1979, kol. 914-917.

76 M. Rusecki, Wychowanie religijne w rodzinie, dz. cyt., s. 302. Por.: R. Goldman, Vorfelder des Glaubens. Kindgemäße religiöse Unterweisung, Vluyn 1972, s. 57; H. Słotwińska, Religia i religijnośc, w: Leksykon pedagogiki religii, dz. cyt., s. 670 .

77 Por. J. Kunstmann, Rückehr der Religion. Glaube, Gott und Kirche neu verstehen, dz. cyt., s. 25-26.

78 T. Ślipko, Zarys etyki ogólnej, dz. cyt., s. 222; Z. Marek, Potencjat religijny wnoszony do wychowania integralnego, „Pedagogika Społeczna” 2015, t. 14, nr 4(58), s. 16-19.

79 Z. Zdybicka, Transcendentne odniesienie cztowieka, dz. cyt., s. 70.

80 M. Nowak, Pedagogika personalistyczna, dz. cyt., s. 237. 
natura, jak i religia. Pośród elementów określających posiadaną przez niego godność w wymiarze naturalnym zwraca się uwagę na uzdolnienia do poznawania, kochania, bycia podmiotem posiadanych praw $^{81}$ czy też korzystania $\mathrm{z}$ wolności ${ }^{82}$. W tym ostatnim przypadku podkreśla się, że wolności nie można ani absolutyzować, ani kwestionować $^{83}$. Chodzi o takie jej wykorzystanie, by władze duchowe człowieka: rozum i wola były w stanie zapanować nad jego zmysłami i namiętnościami ${ }^{84}$.

Wymienione przymioty, określające godność osoby, chrześcijaństwo ubogaca treściami religijnymi. Ukazuje ono godność człowieka wynikającą z relacji z Bogiem. Godność taką człowiek otrzymuje dzięki:

- stwórczemu działaniu Boga, który powołuje go do istnienia;

- wyzwoleniu go z niewoli zła, grzechu i śmierci, którego dokonał Jezus Chrystus na Kalwarii;

- zaproszeniu go do życia z Bogiem w wolności, miłości i szczęściu przez całą wiecznośćs ${ }^{5}$.

Człowiek świadom tych darów ma prawo uważać, że Bóg, który odkupił go przez Jezusa Chrystusa i zaprosił do wspólnoty życia, rzeczywiście go kocha ${ }^{86}$. W ten też sposób godność człowieka ukazuje Boże objawienie, w którym chrześcijanie odkrywają obecność istoty, która sama przedstawia siebie jako absolutny podmiot, dzięki czemu osoba jest również w stanie ukonstytuować się jako podmiot ${ }^{87}$.

81 Por.: Sobór Watykański II, Konstytucja duszpasterska o Kościele w świecie wspótczesnym, nr 25; Z. Marek, Podstawy wychowania moralnego, Kraków 2005, s. 22; J. Mółka, W nurcie personalistycznego wychowania, „Rocznik Wydziału Pedagogicznego WSFP Ignatianum" 2003, s. 73.

82 T. Ślipko, Zarys etyki ogólnej, dz. cyt., s. 221.

83 J. Horowski, Wychowanie moralne wedtug pedagogiki neotomistycznej, dz. cyt., s. 322.

84 Tamże, s. 349; W. Zuziak, Aksjologia Louisa Lavelle'a wobec ponorwoczesnego kryzysu wartości, Kraków 2012, s. 78.

85 Por.: Z. Marek, Podstawy wychowania moralnego, Kraków 2005, s. 20-28; A. Anzenbacher, Co oznacza "godnośc cztowieka”?, „Horyzonty Wychowania” 2006, t. 5, nr 9, s. 61.

86 S. Zarzycki, Cztowiek jako podmiot w ujęciu teologicznym, „Paedagogia Christiana" 2009, nr (2)24, s. 35.

87 H. Waldenfels, Fascynacja chrześcijaństwem, „Horyzonty Wiary” 1997, t. 8, nr 2, s. 11. 


\section{Oferta religii chrześcijańskiej}

Niezależnie od tego, czy człowiek przyjmuje, czy też odrzuca religię, oczywiste zdaje się być stwierdzenie, że wywiera ona swoje piętno na kulturę, a przez nią na ludzkie życie. W dalszej części artykułu skupimy się na dwóch aspektach, które wnoszą poważny wkład w procesy wychowania. Jednym jest możliwość, jaką daje religia, poszerzenia potencjałów poznawczych człowieka, a drugą zdolność do wychodzenia poza doświadczaną ograniczoność.

Walor poznawczy

Jedną z wartości, jaką religia wnosi w życie człowieka, jest nowa jakość poznania. Inspiruje ono zarówno ludzkie myślenie, jak też działanie prowadzące do osiągania życiowych celów ${ }^{88}$. Doświadczenie pokazuje, że korzystając z osiągnięć poznania inspirowanego rozumem i zmysłami człowiek nie jest w stanie spełnić swych tęsknot za „czymś więcej”. Na przeszkodzie staje bowiem niemożność przekraczania granic doświadczanych w czasie i przestrzeni ${ }^{99}$. Tę postać poznania nazywać będziemy poznaniem naturalnym. Daje ono człowiekowi odczuć, że za pomocą swego intelektu nie jest w stanie odpowiedzieć na nurtujące go pytania o początek świata i człowieka, czy też o ich przeznaczenie. Możliwość przekroczenia takich barier daje człowiekowi religia. Poznanie takie nazywamy „poznaniem religijnym" ${ }^{\prime 0}$, które swym zakresem przekracza możliwości poznania ludzkiego intelektu. Oznacza to, że

obok poznania właściwego ludzkiemu rozumowi, który ze swej natury zdolny jest dotrzeć nawet do samego Stwórcy, istnieje poznanie właściwe wierze. Jest to poznanie prawdy opartej na rzeczywistości samego Boga, który się objawia, a więc prawdy niezawodnej, ponieważ Bóg się nie myli, ani nie zamierza zwieść człowieka ${ }^{91}$.

88 Por. M.M. Boużyk, Wychowanie otwarte na religie, dz. cyt., s. 222.

89 P.M. Zulehner, Religia jako mega trend, dz. cyt., s. 22; S. Zięba, Cztowiek. 2. Pochodzenie, dz. cyt., s. 93-99.

90 Pojęcie to stosowane jest w języku religijnym. Wiele uwagi temu zagadnieniu poświęcił papież Jan Paweł II w Encyklice „Fides et ratio” do Biskupów Kościota katolickiego o relacjach między wiara a rozumem z dnia 14 września 1998 roku.

91 Tamże, nr 8. 
Z tego nie wynika jednak, że poznanie religijne udziela człowiekowi zadowalających odpowiedzi na wszystkie jego pytania.

Zasadnicza różnica między poznaniem naturalnym i religijnym polega na różnych źródłach, z których człowiek czerpie wiedzę $e^{22}$. Należy też pamiętać, że

jakkolwiek współobecność wiary i wiedzy może generalnie, jak się zdaje, mieć miejsce we wszelkich doświadczeniach typu rozwojowego, to jednak $\mathrm{z}$ większym prawdopodobieństwem wystąpi ona $\mathrm{w}$ sytuacjach i doświadczeniach o charakterze wyjątkowym, niecodziennym, rzadkim, czyli takich, które dotyczą spraw tajemniczych, kwestii ostatecznych, tzn. mających zasadnicze znaczenie w życiu i rozwoju człowieka ${ }^{93}$.

Przy wyjaśnianiu tej kwestii trzeba też mieć świadomość i tego, że o ile wiedza uważana jest za umotywowane i pewne poznanie, które oznacza duchowe przyswojenie sobie wszystkiego, co daje pewność istnienia na podstawie poznania wynikającego $\mathrm{z}$ własnego wglądu i doświadczenia, to wiara wyraża rezygnację z własnego doświadczenia i wglądu oraz przejęcie określonych zdań i poglądów ze względu na autorytet i świadectwo kogoś drugiego. Wiara wyraża więc zgodę na to, że doświadczenie i naturalna refleksja nad możliwościami poznania są niepełne, niewystarczające. $Z$ tych powodów posługiwanie się wymienionymi formami poznania wymaga respektowania zakresów rzeczywistości, którą każda z nich objaśnia. W przypadku poznania naturalnego człowiek posługuje się naturalną zdolnością poznawczą, jaką jest intelekt, a w przypadku poznania religijnego opiera się na wiedzy przekazanej (objawionej) przez Boga ${ }^{94}$.

Wiara objaśnia rzeczywistość, której rozum nie jest w stanie objaśnić ${ }^{95}$. Jej właściwością jest wkraczanie w rzeczywistość, która dla rozu$\mathrm{mu}$ jest niedostępna. Staje się przez to bardzo osobistym aktem człowieka. Dlatego wierzyć, to przede wszystkim uznać za prawdę to, czego do końca nie ogarnia nasz umysł; przyjąć to, co Bóg objawia o sobie, o człowieku i o całej rzeczywistości, także tej niewidzialnej, niepojętej,

92 Tamże, nr 9.

93 R. Schulz, Wyktady z pedagogiki ogólnej, t. 2: O integralnq wizję człowieka i jego rozwoju, Torun 2007, s. 129.

94 Jan Paweł II, Encyklika „Fides et ratio”, dz. cyt., nr 9. Por. H. Waldenfels, O Bogu, Jezusie Chrystusie i Kościele dzisiaj, tłum. A. Paciorek, Katowice 1993, s. 317.

95 Szerzej zob. Z. Marek, Religia pomoc czy zagrożenie dla edukacji?, Kraków 2014, s. 49 i nn. 
niewyobrażalnej. W tym sensie prawda objawiona poszerza horyzont ludzkiego poznania. Pozwala ona dotrzeć do tajemnicy, w jaką zanurzona jest egzystencja człowieka. Dlatego też wyrażenie zgody na ograniczone możliwości poznania za pomocą rozumu nie jest dla człowieka łatwe ${ }^{96}$. Wszystko to pokazuje, że zdolność do posługiwania się poznaniem religijnym otwiera przed człowiekiem nowe perspektywy postrzegania i rozumienia zarówno siebie, jak i świata, w którym żyje. $\mathrm{Na}$ tej drodze otrzymuje on pełniejsze objaśnienie sensu swego życia oraz nową motywację do angażowania się na rzecz dobra innych.

Walor rozwojow y

Poza poznaniem religijnym dla procesów wychowania znaczenie posiada także wyrastająca $\mathrm{z}$ cielesno-duchowej natury człowieka sfera duchowa. Wskazuje ona na konieczność respektowania w wychowaniu nie tylko jego potrzeb biologicznych i materialnych, ale też na równi z nimi potrzeb duchowych (wewnętrznych). Chodzi o dowartościowanie rzeczywistości niematerialnej, którą powszechnie nazywamy „„ferą

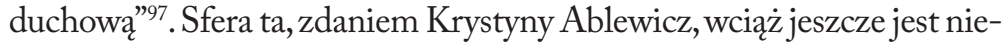
dowartościowana $\mathrm{w}$ środowiskach pedagogów, o czym świadczy chociażby to, że w literaturze przedmiotu rzadko pojawiają się takie pojęcia jak: „duch”, ,rozwój duchowy”, ,duchowość”. Terminów tych nie odnajdujemy w badaniach podejmujących zagadnienia związane wartościami/filozofią człowieka, kierunkami/nurtami/prądami czy nawet samym wychowaniem ${ }^{98}$. Wyjątkiem w tym zakresie jest literatura teologiczna. Ta nieobecność ducha w procesie wychowania, tłumaczy K. Ablewicz,

została wywołana wtórnie, jako konsekwencja metodologicznego rozbicia całościowo doświadczanego fenomenu procesu wychowania człowieka, wzmacniając tym samym utrwalany kulturowo i mentalnie kartezjański dualizm, rozdwajający człowieka na substancję cielesną i substancję (rzecz) myśląca, nazywaną w tym przypadku dusząa ${ }^{99}$.

96 Benedykt XVI, Trwajcie mocni w wierze. Pielgrzymka do Polski, Warszawa 2006, s. 81.

97 Por. Z. Marek, Duchowośc, religia i wychowanie, „Pedagogika Społeczna” 2015, t. 14, nr 1(55), s. 11-13.

98 K. Ablewicz, (Nie)obecnośc ducha w wychowaniu człowieka, dz. cyt., s. 59-60.

99 Tamże, s. 65. 
Termin „duchowość” swym źródłosłowem nawiązuje do łacińskiego terminu spiritualitas, który zaczął występować w literaturze chrześcijańskiej już w $\mathrm{V}$ wieku. Jego wprowadzenie przypisuje się Pelagiuszowi bądź któremuś z jego uczniów. Pojęcie to w ciągu wieków przechodziło trwającą do dziś dzień ewolucję znaczeniową, której przyczyn należy doszukiwać się w uwarunkowaniach kulturowo-historyczno-geograficznych ${ }^{100} . Z$ racji swego pierwotnego znaczenia termin ten często utożsamiano $\mathrm{z}$ religią. Zamienne używanie pojęć: „religia” i „duchowość” bywa efektem fałszywego kojarzenia religii z takimi określeniami jak: fanatyzm, nietolerancja i przemoc. Ponieważ wielu nie akceptuje takich działań, łatwo zrozumieć dlaczego uważają, że „lepiej jest nie mieć z tym nic wspólnego i posługiwać się nieszkodliwym słowem «duchowość», które brzmi bardziej niewinnie, kojarzy się z otwartością na świat i oświeceniem"101. Terminem „duchowość" określa się wiele zróżnicowanych form warunkowanych przynależnością do zinstytucjonalizowanej konfesji, tradycji kulturowej, formacji wewnątrzkonfesyjnej czy stylu epoki ${ }^{102}$. Termin ten zazwyczaj uzupełniany jest przymiotnikiem określającym rodzaj duchowości, o którą chodzi: np. duchowość chrześcijańska, prawosławna, buddyjska, benedyktyńska, baroku czy współczesna ${ }^{103}$.

Początkowo pojęciem „duchowość” posługiwano się wyłącznie w znaczeniu religijnym. Miało ono oznaczać postępowanie sprzyjające wzrostowi duchowemu. Jego przeciwieństwem był termin „cielesność", który wyrażał rzeczywistość materialną i aktywność człowieka ${ }^{104}$. W rzeczywistości termin ten swym znaczeniem wykracza poza rzeczywistość religijną i dlatego pod żadnym pozorem nie jest równoważny z pojęciem „religia”. Wprawdzie duchowość nie istnieje

100 Por. J. Wiseman, Historia duchowości chrześcijańskiej. Wybrane zagadnienia, tłum. A. Wojtasik, Kraków 2009.

101 T. Meurer, Duchowość jako zamiennik religii? Wyprawy w mgliste pogranicze religii i duchowości, „Keryks”2011, t. 10, s. 151,

102 Por.: T. Olchanowski, Duchowośc i narcyzm, Warszawa 2006, s. 141; W. Pawluczuk, Duchowosí, w: Leksykon socjologii religii. Zjawiska - badania - teorie, red. M. Libiszowska-Żółtkowska, J. Mariański, Warszawa 2004, s. 90.

103 W. Pawluczuk, Duchowośc, w: Leksykon socjologii religii. Zjawiska-badaniateorie, dz. cyt., s. 90.

104 M. Chmielewski, Duchowość, w: Leksykon duchowości katolickiej, red. M. Chmielewski, Lublin - Kraków 2002, s. 226. Por. J. Wiseman, Historia duchowości chrześcijańskiej, dz. cyt., s. 18-21. 
jako byt fizyczny, to jednak posiada w sobie istnienie bogatsze i szlachetniejsze - duchowe, właściwe poznaniu i miłości ${ }^{105}$. Jest uważana za termin prosty, niedefiniowalny ${ }^{106}$, który objaśnia egzystencję ${ }^{107}$ i dążenia osoby do życia, szczęścia oraz miłości ${ }^{108}$. Współcześnie duchowość łączy się nie tylko z praktyką życia duchowego (sens subiektywny) i usystematyzowaną refleksją nad nim (sens obiektywny), ale też z praktyką życia bez odwoływania się do Transcendencji/Boga. Przyczynił się do tego między innymi Jacques Delors, który w latach 90. XX wieku promował termin „europejska duchowość”. Jej podstaw doszukiwał się w dziedzictwie historycznym, które uważał za powód do dumy i podziwu każdego z krajów europejskich ${ }^{109}$.

James i Melissa Griffith określają duchowość mianem wyboru "pewnego rodzaju zobowiązania i zaangażowania wobec wszystkiego, co istnieje, które stają się głównym kontekstem rozumienia świata i działania w nim”"110. Duchowość wyraża „wspólnotę sensu wartości, sensu rząadzącego określonymi strukturami. Mogą być to sensy życia indywidualnego, sensy sytuacyjne, ale też i korporacyjne, narodowe, religijne" ${ }^{111}$. Stąd przyjmuje się, że jest to termin antropologiczny, odwołujący się do właściwości natury człowieka: doświadczenia transcendencji, które umożliwia poznanie jako osoby oraz jej duchowego istnienia. Przypisuje się jej zdolność kształtowania zarówno stylu życia, jak też prądów kulturowych oraz sposób sprawowania kultu. Oznacza również formę życia, która opiera się na akceptowaniu nad-

105 J. Horowski, Wychowanie moralne wedtug pedagogiki neotomistycznej, dz. cyt., s. 203. Por. W. Zuziak, Aksjologia Louisa Lavelle'a wobec ponowoczesnego kryzysu wartości, dz. cyt., s. 72-74.

106 Por. M. Chmielewski, Duchowość, w: Leksykon socjologii religii. Zjawiska badania-teorie, dz. cyt., s. 229.

107 L. Marszałek, Duchowośc dziecka. Znaczenia-perspektywy - konteksty w pedagogice przedszkolnej, Warszawa 2013, s. 27 nn.

108 Por.: L.F. Ladaria, Wprowadzenie do antropologii teologicznej, dz. cyt., s. 1415; A. Gałdowa, A. Nelicki, O możliwościach $i$ warunkach bycia twórczym z perspektywy aksjologicznej teorii wartości, dz. cyt., s. 7-28; T. Meurer, Duchowość jako zamiennik religii?, dz. cyt., s. 158.

109 H. Lombaerts, Edukacja z perspektywy europejskiej, „Horyzonty Wychowania" 2002, t. 2, nr 3, s. 169.

110 J.L. Griffith, M.E. Griffith, Odkrywanie duchowości w psychoterapii, dz. cyt., s. 45. Por. J. Wiseman, Historia duchowości chrześcijańskiej, dz. cyt., s. 21-25.

111 K. Ablewicz, (Nie)obecność ducha w wychowaniu cztowieka, dz. cyt., s. 77. 
rzędnej wartości, jaką dla człowieka jest sacrum ${ }^{112}$. Wskazuje nadto, że jest ona powiązana $\mathrm{z}$ ludzkimi dążeniami do najwyższego celu, jakim jest Bóg ${ }^{113}$. Duchowość wyraża zatem właściwość człowieka, która „istnieje sama przez się, jest przedmiotem samorzutnych przejawów myśli, mowy, ocen, dążeń, twórczości i porywów ponad doczesność i zmysłowość" - uważa Stefan Kunowski ${ }^{114}$. Kształtują ją różne czynniki, które wymagają nie tylko rozwoju, ale też właściwego nastawienia osoby ku Logosowi prawdy i łaski. Nastawienie to obrazuje duchowość religijną, której istotną właściwością jest akceptacja sacrum jako wartości nadrzędnej, nadającej sens egzystencji człowieka i jego dążeniom do osiągania doskonałości. Łączy ona w jedno religijność oraz sposób jego życia ${ }^{115}$.

Duchowość współtworzą: świadomość (poznanie), emocjonalność (uczucia) oraz wartości (w tym religijne) wraz z przyjmowaną $i$ akceptowaną ich hierarchią̨ ${ }^{116}$. Wynika $\mathrm{z}$ tego, że duchowość nie jest czymś statycznym, lecz aktywnym. Co więcej, „będąc pojęciem wielowymiarowym, obejmuje zarówno pogłębione życie religijne, w tym również różne światopoglądy, jak i kompetencje poznawcze rozumienia siebie i świata oraz posiadanie świadomie kształtowanego wymiaru moralnego" ${ }^{117}$. Jej istnienie człowiek wyraża za pośrednictwem takich wartości jak: „praca, myśl, symbole, mowa, sztuka, zabawa, kultura, nauka itp." ${ }^{118}$. Przy objaśnianiu jej istoty mamy do czynienia zarówno z przywoływaniem naturalnych, jak i religijnych przesłanek. To z kolei pozwala mówić o duchowości naturalnej albo religijnej ${ }^{119}$. Zwolennicy duchowości naturalnej podkreślają, że odwołuje się ona

112 Por. S. Witek, Duchorwośc religijna, w: Encyklopedia katolicka, t. 4, red. R. Łukaszyk, L. Bieńkowski, F. Gryglewicz, Lublin 1989, kol. 330-331.

113 Por. J.A. Wiseman, Historia duchowości chrześcijańskiej, dz. cyt., s. 25.

114 S. Kunowski, Podstawy wspótczesnej pedagogiki, Łódź 1981, s. 215.

115 Por. S. Witek, Duchowośc religijna, w: Encyklopedia katolicka, t. 4, dz. cyt., kol. 330.

116 M. Chmielewski, Duchowośc, w: Leksykon socjologii religii, dz. cyt., s. 229.

117 J. Surzykiewicz, Religia, religijnośc i duchowość jako zasoby osobowe i kapitat spoteczny w pedagogice spotecznej/pracy socjalnej, „Pedagogika Społeczna” 2015 , t. 14, nr 1(55), s. 31.

118 L. Marszałek, Duchowośc dziecka, dz. cyt., s. 33.

119 M. Chmielewski, Duchorwość, w: Leksykon duchowości katolickiej, dz. cyt., s. 227; L. Marszałek, Duchowośc dziecka, dz. cyt., s. 30. 
do immanencji ludzkiego bytu, ponieważ wyraża najbardziej ukryty element, z którego promieniuje dynamizm ludzkiego ducha. Jej naturalnego wymiaru nie należy uważać za przymioty drugorzędne ${ }^{120}$, choćby dlatego, że kieruje człowieka ku „wyższej sile”, „wyższemu porządkowi”, który istnieje poza nim. Nie znaczy to, że człowiek jest w stanie zawsze tę siłę nazwać bądź określić. Nie przeszkadza to, że czuje się od niej zależny ${ }^{121}$.

Szczególną formą duchowości, z jaką mamy do czynienia w naszym kręgu kulturowym, jest duchowość chrześcijańska. W ciągu wieków duchowość ta przyjmowała różne postaci. Zawsze jednak wyrażała dążenie człowieka do zjednoczenia z Bogiem przez Jezusa Chrystusa. Nastawienie to wyrasta i jest inspirowane głoszoną przez Jezusa Ewangelią i wynikającymi z niej konsekwencjami ${ }^{122}$. Pośród prób bardziej szczegółowego opisu duchowości warto zatrzymać się na dwóch. Pierwszą sformułował Stefan Kunowski ${ }^{123}$. Przypisuje on duchowości następujące cechy: rozumność, zdolność do wartościowania i oceniania, wolność, twórczość, otwartość. Inna próba wyjaśnienia tego czym jest duchowość została podjęta przez Davida L. Fleminga ${ }^{124}$. Przywołując dynamizm ludzkiego działania, duchowość nazwał zbiorem postaw, zwyczajów (tradycji) i wartości, które promuje konkretna osoba. Zbiór ten kreśli „drogę ludzkiego postępowania”, promując wizję życia, refleksyjny stosunek do codzienności, pełne szacunku nastawienie do świata i nadzieja na pełne odnalezienie Boga (nieśmiertelności). W tym ujęciu charakterystyczne wydaje się być zwrócenie uwagi na powiązania i związki zachodzące między zajmowanymi przez osobę postawami, przywoływanymi zwyczajami oraz akceptowanymi wartościami.

Postrzeganie duchowości w ujęciu D.L. Fleminga pokazuje, że człowiek swe postawy wyraża za pośrednictwem stałego sposobu

120 M. Daniluk, Duchowość chrześcijańska, w: Encyklopedia katolicka, t. 4, dz. cyt., kol. 317.

121 S. Witek, Duchowość religijna, dz. cyt., s. 330.

122 Por. M. Daniluk, Duchowość chrześcijańska, w: Encyklopedia katolicka, t. 4, dz. cyt., kol. 317.

123 S. Kunowski, Podstawy wspótczesnej pedagogiki, dz. cyt., s. 210-211.

124 D.L. Fleming, Czym jest duchowość ignacjanska?, tłum. D. Piórkowski, Kraków 2013, s. 5-6; por. T. Meurer, Duchowoś́ jako zamiennik religii?, dz. cyt., s. 158. 
zachowania, który obrazuje stan jego świadomości ${ }^{125}$. Za jej pośrednictwem wyraża swe względnie stałe zachowania obrazujące pozytywne lub negatywne reakcje na otaczającą go rzeczywistość. Mogą one przyjmować postać intelektualno-orientacyjną (poznawczą), emocjonalno-motywacyjną oraz behawioralną ${ }^{126}$. Postawą można też nazywać

wyuczoną cechą osobowości, która warunkuje specyficzny sposób zachowania się jednostki wobec czegoś. Ów specyficzny sposób zachowania to zobojętnienie wobec czegoś, uznanie, aprobata, miłość, nienawiść, trwoga, wdzięczność, izolowanie, uznanie za swoje bliskie lub obce i wrogie ${ }^{127}$.

Dlatego też przy udzielaniu wsparcia wychowawczego trzeba brać pod uwage to, że w toku nabywania konkretnych postaw pojawiają się czynności dynamiczne, którymi są potrzeby i związane z nimi dążenia, pragnienia, emocje, uczucia, a nadto czynności poznawcze i czynności motoryczne. Stają się one siłą napędową wspierającą rozwój osoby, efektywność jej działań i harmonijne funkcjonowanie w większych społecznościach. Spełnienie zarysowanych oczekiwań domaga się harmonijnej współpracy wszystkich podmiotów procesu wychowania: rodziców, władz państwowych, wychowanków i pedagogów. Jej podstawą ma być partnerstwo, a nie wydawanie i wykonywanie rozkazów ${ }^{128}$.

Harmonijna współpraca środowisk wychowawczych wyzwala w człowieku motywy, dzięki którym łatwiej mu znaleźć uzasadnienie ważności wskazywanych postaw. Motywy rodzą się bowiem pod wpływem odkrywanych potrzeb, które ukazują realny brak występujący bądź to w życiu osobistym, bądź też w życiu innych osób. Przekonanie o potrzebie uzupełnienia dostrzeganego braku staje się motywem ludzkiego działania. Budzące się potrzeby uzupełnienia dostrzeganego braku pojawiają się zasadniczo w dwóch postaciach:

125 Por. Z. Marek, Podstawy wychowania moralnego, dz. cyt., s. 102-108.

126 Por.: W. Prężyna, Funkcja postawy religijnej w osoborwości cztowieka, Lublin 1981, s. 20; T. Mądrzycki, Psychologiczne prawidtowości ksztattowania sie postaw, Warszawa 1977, s. 24-25.

127 J. Bazylak, Postawy religijne mtodzieży i ich zwiqzki z wybranymi elementami osobowości, Warszawa 1984, s. 5; por. W. Prężyna, Intensywność postawy religijnej, a osobowość, Lublin 1973, s. 25.

128 Por. E. Josef Korherr - Studien zur religiösen Erziehung und Bildung, red. E. Rauscher, H.-F. Angel, M. Langer, Hamburg 2008, s. 119. 
jako potrzeby biologiczne, które warunkują rozwój biologicznej struktury organizmu, i jako potrzeby psychiczne (psychologiczne) wspierające rozwój osobowości. W toku procesów wychowania jedne i drugie zostają częściowo zaspokajane i częściowo niezaspokajane. Ich zaspokajanie przebiega stopniowo, płynnie i charakteryzuje się powolnymi zmianami ${ }^{129}$.

Poza postawami wpływ na rozwój duchowości wywiera odkrywana i przywoływana tradycja. Termin „tradycja” wywodzi się z łacińskiego słowa traditio i oznacza przechowywanie, wręczanie, przekazywanie, podawanie oraz nauczanie. Jest to pojęcie wieloznaczne, które odnosi się do związków współczesności z przeszłością. W szerszym znaczeniu tradycja

oznacza to wszystko, czego pokolenia obecnie żyjące nie stworzyły dopiero co same, lecz co zawdzięczają pokoleniom wcześniejszym lub własnej dawniejszej działalności [...]. Idzie przy tym nie o osiągnięcia materialne, lecz o wartości, instytucje społeczne, sposób życia, wzory myślenia i postępowania. Zakres tak rozumianej tradycji pokrywa się w dużym stopniu z zakresem pojęcia «kultura», które w ujęciu większości teoretyków obejmuje przecież głównie to, co uległo już utrwaleniu i w toku socjalizacji podlega przekazywaniu nowym członkom zbiorowości ${ }^{130}$.

Zazwyczaj tradycja łączona jest $\mathrm{z}$ indywidualnymi nawykami osoby żyjącej w większej zbiorowości, której członkowie respektują istniejący porządek bez zaistnienia jakichkolwiek oficjalnych nakazów oraz sankcji. Jego cechą jest trwałość, która nie przemija tak szybko, jak na przykład sezonowo zmieniająca się moda. W zjawisku tym istotny jest przykład innych osób. Człowiek stosując się do zwyczaju nie potrzebuje uzasadnienia swojego postępowania. Ma przy tym poczucie, że inni też tak postępują. Dlatego też zwyczaje uważane są za część szeroko rozumianej tradycji1 ${ }^{131}$. Przenosząc te uwagi na płaszczyznę duchowości, podkreślmy że chodzi o działania umożliwiające osobie określenie własnej tożsamości. Jest to możliwe, jeśli poprzez kontakt ze swoją historią i kulturą odnajdzie swe „korzenie”

129 Por. A.H. Maslow, Motywacja i osobowość, tłum. P. Sawicka, Warszawa 1990, s. 74.

130 J. Szacki, Tradycja, w: Stownik spoteczny, red. B. Szlachta, Kraków 2004, s. 1491.

131 Por. Zwyczaj, w: Wielka encyklopedia PWN, t. 30, red. J. Wojnowski, Warszawa 2005, s. 484. 
określające jej tożsamość. Podstawą do takich działań winny być odkrywane związki łączące człowieka $\mathrm{z}$ innymi osobami oraz $\mathrm{z}$ większą społecznością, w której wzrasta, rozwija się i żyje, a także relacje z Transcendencją/Bogiem ${ }^{132}$.

Poza postawami i respektowanymi tradycjami duchowość wyrażają przyjmowane przez osobę wartości. Wyznaczają one kryteria i normy ludzkiego postępowania. Termin „wartość” pochodzi od łacińskiego słowa: valor lub valere i oznacza wartość, być wartym. Wartością można więc nazwać to wszystko, co jest dobrem. Odnosi się ona zarówno do konkretnej rzeczywistości, jak i cennych dla człowieka dóbr. Mogą to być dobra materialne: majątek, życie, zdrowie, jak też dobra duchowe: wiedza, prawda, moralność, prawo, religia, sztuka. Według innej klasyfikacji można mówić o wartościach podstawowych takich, jak małżeństwo, rodzina, gospodarka rynkowa, demokracja, czy państwo prawa; o wartościach wiecznych - nieprzemijających, takich jak prawda, dobro i piękno; o wartościach religijnych, takich jak wieczność, nieśmiertelność, życie wieczne z Bogiem itd. ${ }^{133}$. Wartości wieczne odnoszą się do uznanej wartości absolutnej. Uczą też respektowania związków łączących człowieka z Sacrum/ Transcendencją/Bogiem ${ }^{134}$.

Chociaż termin „wartość” charakteryzuje duża ogólność i abstrakcyjność, to jednak posiada on ogromny zasięg odnoszący się do wielkiej liczby przedmiotów, a jego kategorie dotyczą norm, sądów i ocen moralnych ${ }^{135}$. Za jego pomocą łatwiej przychodzi człowiekowi odnaleźć orientację w tym, co dla osoby i społeczeństwa jest ważne, cenne, godne pożądania; co wywołuje pozytywne odczucia, a jednocześnie odsłania cel dalszych życiowych dążeń. Wartości stają się więc swego rodzaju miernikiem (kryterium) oceny osób, rzeczy, zjawisk lub norm, dostarczając tym samym podstaw uznania czegoś

132 Por. J. Nikitorowicz, Tradycja, w: Encyklopedia pedagogiczna XXI wieku, t. 6, red. T. Pilch, Warszawa 2007, s. 773.

133 W. Brezinka, Wychowanie i pedagogika w dobie przemian kulturowych, tłum. J. Kochanowicz, Kraków 2005, s. 19.

134 Por. K. Olbrycht, Wychowanie do wartości - w centrum aksjologicznych dylematów wspótczesnej edukacji, „Paedagogia Christiana” 2009, nr (2)24, s. 102.

135 Por.: W. Brezinka, Wychowywać dzisiaj. Zarys problematyki, tłum. J. Kochanowicz, Kraków 2007, s. 22; Z. Marek, Podstawy wychowania moralnego, dz. cyt., s. 34-35. 
za dobre lub złe. Posiadają one swój specyficzny osobowościowo-powinnościowy charakter. Stanowią przy tym nie tylko kryterium oceny rozstrzygania o tym, czy coś jest wartościowe lub niewartościowe, ale są samym dobrem identyfikowanym $z$ przedmiotem oceny ${ }^{136}$, co zezwala na nazywanie ich wartościami moralnymi. Walorów tych należy się doszukiwać w ich transcendentnym pochodzeniu. Są wartościami par excellence osobowymi, gdyż pozostają wyłącznie w relacjach do osoby. Dlatego też $\mathrm{w}$ procesach wychowawczych nadaje się im pierwszeństwo przed innymi wartościami i uważa się je za niezbędne do pełnego rozwoju osoby ${ }^{137}$.

Wartości w wychowaniu przenikają, poruszają i kształtują świadomość człowieka, wywołują przeżycia i pobudzają do działania, a także wytyczają cele działań, scalają je i ich wytwory, integrują ludzi i społeczeństwa, stymulują, ukierunkowują oraz stabilizują ich rozwój. Z kolei wiedza o nich wprowadza osobę w świat dóbr kultury i umożliwia ich współtworzenie. $Z$ tych też powodów możliwość odwoływania się do niej jest dla wychowania istotna, bo umożliwia formułowanie wniosków natury etyczno-kulturowej ${ }^{138}$. Można więc powiedzieć, że troska o poznawanie i kierowanie się nimi w życiu codziennym służy obronie człowieka ${ }^{139}$. Nowe warunki życia, w jakich dzisiaj przychodzi młodemu człowiekowi funkcjonować, wskazują na potrzebę udzielania mu wsparcia w odkrywaniu i wybierania dobra, a zwłaszcza dobra wspólnego. Dlatego tak ważne jest postrzeganie i ukazywanie dobra jako podstawowego kryterium doboru treści przekazywanych w toku procesów wychowania oraz stosowania określonych form wychowawczych ${ }^{140}$. Tak więc analiza wskazanego przez D.L. Fleminga zbioru postaw, tradycji i wartości pokazuje, że między tymi elementami dochodzi do interakcji z osobistymi uwarunkowaniami osoby i otoczenia oraz z posiadaną wolnością. Sama

M. Łobocki, Wychowanie moralne w zarysie, Kraków 2002, s. 72. cyklopedia aksjologii pedagogicznej, red. K. Chałas, A. Maj, Radom 2016, s. 1251-1254.

138 B. Żurakowski, Humanizm pedagogiki kultury, w: Pedagogika kultury - wychowanie do wyboru wartości, red. B. Żurakowski, Kraków 2003, s. 15.

139 L. Dyczewski, Miejsce i funkcja wartości w kulturze, „Keryks” 2008, t. 7, s. 58-61.

140 M. Eobocki, Wychowanie moralne w zarysie, dz. cyt., s. 204. 
zaś duchowość umożliwia osobie przekraczanie granic nauk przyrodniczych, aby móc „podążać w kierunku czegoś, co nadaje życiu i egzystencji sens i wartość - ku wartościom i to nie $z$ racji takich czy innych, lecz z racji uznania samych wartości jako wartości”141.

\section{Wkład religii w procesy wychowawcze}

Walor niematerialny, wewnętrzny, czy też duchowy natury człowieka umożliwia wychodzenie poza granice kreślone przez ludzką cielesność i zewnętrzność. Jest to swoista nobilitacja człowieka. $\mathrm{W}$ jej następstwie człowiek, pozostając fizycznym bytem osobowym, staje się jednocześnie bytem „ponadfizycznym”, skierowanym ku innym stopniom doskonałości, ku Transcendencji - Bogu ${ }^{142}$. Przyjmując ten tok rozumowania, powiemy, że charakterystycznym rysem pedagogiki transcendentnej jest odwoływanie się do rzeczywistości ponadnaturalnej. W chrześcijańskim rozumieniu w jej centrum jest osobowy Bóg, który nie jest dla człowieka fikcją, lecz realną rzeczywistością - osobą, z którą człowiek może nawiązać relacje. To właśnie one w sposób zasadniczy wpływają na jego funkcjonowanie zarówno w życiu indywidualnym, jak też społecznym. Tym samym sprzyjają pozytywnemu nastawieniu osoby do życia oraz zajmowaniu określonych życiowych postaw, pośród których Bóg i Jego obietnice stają się przedmiotem jej pragnień. Dzieje się tak dlatego, że człowiek świadomy własnej ograniczoności poszukuje pomocy w spełnieniu swych dążeń u kogoś innego - sacrum. Karl Rahner, twórca antropologii transcedentalnej, uzasadnia te dążenia tym, że w każdym człowieku mocno tkwi pragnienie szczęścia, dobra, piękna, których sam nie może w pełni zrealizować ze względu na swą ograniczoność ${ }^{143}$. W nurt takiego myślenia wpisuje się wspomniana na wstępie artykułu „pedagogika transcendentna”. Bogusław Śliwerski, powołując się na Ulricha Schrade, zauważył, że jedne z nurtów filozoficznych przyjmują, a inne odrzucają istnienie

141 M. Nowak, Osoba i wartość w pedagogice ogólnej, w: Antropologiczna pedagogika ogólna, red. M. Nowak, P. Magiera, I. Szewczak, Lublin 2010, s. 48.

142 Por. Z. Marek, Podstawy wychowania moralnego, dz. cyt., s. 16.

143 K. Rahner, H. Vorgrimler, Transcendencja, w: Maty stownik teologiczny, dz. cyt., s. 500-501. 
w świecie nie tylko sił naturalnych, ale też sił duchowych (pozanaturalnych), które nadto nie podlegają prawom przyrody ${ }^{144}$.

Dopuszczenie możliwości postrzegania rzeczywistości otaczającej człowieka zarówno za pomocą empirii i rozumu, jak też poznania religijnego stawia przed pedagogiką nowe wyzwania. Chodzi o rozwiązania, które będą godzić rzeczywistość empiryczną i ponadnaturalną. Władna tego dokonać jest „pedagogika transcendentna”, którą identyfikujemy z autonomiczną subdyscypliną nauki nazywaną "pedagogiką religii" ${ }^{45}$. Subdyscyplina ta pod żadnym pozorem nie rości sobie praw do zastępowania pedagogiki ogólnej. W przypadku chrześcijaństwa odwołuje się ona do chrześcijańskich założeń antropologiczno-filozoficzno-teologicznych. Jej najgłębszych korzeni należy się doszukiwać $\mathrm{w}$ personalizmie ${ }^{146} \mathrm{i}$ antropologii chrześcijańskiej ${ }^{147}$. Ten sposób postrzegania pedagogiki religii uprawnia do uważania jej za subdyscyplinę naukową, która została oparta na i usytuowana na pograniczu pedagogiki i teologii ${ }^{148}$.

W badaniach prowadzonych przez przedstawicieli pedagogiki religii dąży się do znalezienie możliwości i sposobów udzielania człowiekowi wsparcia w osiąganiu dojrzałości ludzkiej i religijnej oraz w nabywaniu umiejętności korelowania wiary z życiem ${ }^{149}$. Źródłem tych dociekań jest zarówno Boże objawienie, jak i ludzka codzienność. Jej przedstawiciele w swych badaniach podejmują refleksję nad rzeczywistością boską i ludzką, zmierzając do rozpoznania, w jaki sposób religie i Kościoły zostają włączone w ludzkie konteksty życia politycznego, ekonomicznego, kulturowego czy społecznego ${ }^{150}$. Dąży się nie - chrześcijańska koncepcja Stefana Kunowskiego, Kielce 2012, s. 27-74. Por.: B. Stańkowski, Salezjański system wychowania mtodzieży - możliwe wypaczenia, „Seminare” 2011, nr 30, s. 187-194; L. Grzebień, Pedagogika ignacjanska na tle innych pedagogik zakonnych (refleksje nad dziejami szkolnictwa polskiego), w: Pedagogika ignacjańska. Historia, teoria, praktyka, red. A. Królikowska, Kraków 2010, s. 107-128.

B. Śliwerski, Pedagogika bez transcendencji, dz. cyt., s. 80-81.

Z. Marek, Religia pomoc czy zagrożenie dla edukacji?, dz. cyt., s. 158.

Por. Z. Marek, Religia pomoc czy zagrożenie dla edukacji?, dz. cyt., s. 56 i nn.

G. Hilger, S. Leimgruber, H.-G. Ziebertz, Religionsdidaktik. Ein Leitfaden für Studium Ausbildung und Beruf, München 2001, s. 31.

Por. N. Mette, Religionspädagogik, Düsseldorf 1994, s. 241.

G. Hilger, S. Leimgruber, H.-G. Ziebertz, Religionsdidaktik, dz. cyt., s. 18. 
więc do opisu rzeczywistości wychowawczej rozpatrywanej zarówno w kontekście Bożego objawienia, jak też osiągnięć współczesnej humanistyki i nowocześnie rozumianej teologii ${ }^{151}$. Będąc autonomiczną dyscypliną nauki, pedagogika religii zajmuje się badaniem i formułowaniem zasad oraz teorii własnego funkcjonowania oraz interpretowaniem empirycznie poznawanych spraw ludzkiego życia w świetle objaśnień treści podawanych przez religie. Nadto określa właściwe swemu charakterowi: cel, zakres i metody badawcze ${ }^{152}$. Korzysta przy tym $\mathrm{z}$ dorobku nie tylko nauk o wychowaniu, ale i innych dyscyplin, w tym także teologii, zachowując jednocześnie swe podstawowe nastawienie na interpretowanie ludzkiej egzystencji w świetle treści religijnych. Tym samym kieruje się ku rozwijaniu teorii kształcenia religijnego oraz socjalizacji religijnej w obszarze życia Kościoła, rodziny, szkoły i społeczeństwa, korzystając ze źródeł religijnych (Bożego objawienia) oraz źródeł dostępnych naukom humanistycznym (psychologia, socjologia, pedagogika) ${ }^{153}$.

Walorem pedagogiki religii jest naukowa refleksja nad możliwościami niesienia pomocy w rozumieniu rzeczywistości codziennego życia w świetle wiary w Boga. Istotą tego towarzyszenia jest świadectwo drugiego człowieka (wychowawcy), który z wychowankiem dzieli się własnymi doświadczeniami relacji z Transcendencją - Bogiem i wynikającym $z$ tego nowym postrzeganiem własnego życia oraz funkcjonowania świata. Charakterystyczne jest też i to, że jej zainteresowania skupiają się na człowieku. Stąd też jako dyscyplina naukowa poszukuje ona możliwości niesienia człowiekowi wsparcia, swoistego towarzyszenia w dążeniu do wyznaczanych mu celów. Pokazuje to, że jednym z jej zadań jest poszukiwanie możliwości towarzyszenia człowiekowi $\mathrm{w}$ jego codzienności oraz udzielanie mu wsparcia w stawaniu się człowiekiem dojrzałym i odpowiedzialnym. Istotą tego towarzyszenia jest nie tylko bycie $\mathrm{z}$ osobą, ale przede wszystkim odkrywanie nowych horyzontów, a co za tym idzie sensu własnego życia. Działalność tę potocznie nazywamy wychowaniem religijnym.

151 Por. B. Milerski, Hermeneutyka pedagogiczna. Perspektywy pedagogiki religii, Warszawa 2011, s. 207.

152 W. Simon, Pedagogika religii w Niemczech, w: Leksykon pedagogiki religii, red. C. Rogowski, Warszawa 2007, s. 567.

153 Por. Z. Marek, Religia pomoc czy zagrożenie dla edukacji?, dz. cyt., 54-65. 
Przedłożenie o związkach zachodzących między religią, poznaniem i duchowością człowieka nie jest, jak to zostało wspomniane, oczywiste dla wszystkich i nie przez wszystkich uznawane. W tym przypadku mamy do czynienia $\mathrm{z}$ autentyczną wolnością człowieka, który z określonych powodów zajmuje w życiu takie, a nie inne stanowisko. Dopuszczając możliwość odwoływania się człowieka do rzeczywistości transcendentnych, możemy mówić o wsparciu, jakiego religia udziela do osiągania szeroko pojmowanej dojrzałości rozumianej jako wewnętrzny jego stan. Niezmienność zasad proponowanych przez religię daje poczucie bezpieczeństwa i stabilności życiowej. $Z$ kolei eksponowana przez duchowość rzeczywistość niematerialna ludzkiego życia zdaje się poszerzać w istotny sposób rozumienie siebie i sensu własnej egzystencji odkrywanej dzięki poznaniu religijnemu.

\section{Bibliografıa}

\section{Dokumenty}

Benedykt XVI, Trwajcie mocni w wierze. Pielgrzymka do Polski, KAI, Warszawa 2006.

Katechizm Kościoła katolickiego, Pallottinum, Poznań 1994.

Deklaracja o wychowaniu chrześcijańskim, w: Sobór Watykański II, Konstytucje, dekrety, deklaracje, Pallottinum, Poznań 2002.

Konstytucja duszpasterska o Kościele w śrwiecie wspótczesnym, w: Sobór Watykański II, Konstytucje, dekrety, deklaracje, Pallottinum, Poznań 2002.

\section{Opracowania}

Ablewicz K., (Nie)obecnośc ducha w wychowaniu cztowieka. Z fllozofii kultury Bogdana Nawroczyńskiego, „Horyzonty Wychowania” 2007, t. 6, nr 11, s. 57-79.

Adamski F., Personalistyczna wizja kultury, w: Pedagogika kultury-wychowanie do wyboru wartości, red. B. Żurakowski, Oficyna Wydawnicza „Impuls", Kraków 2003, s. 27-35.

Adamski F., Wprowadzenie: Personalizm - filozoficzny nurt myślenia o cztowieku i wychowaniu, w: Wychowanie personalistyczne. Wybór tekstów, red. F. Adamski, Wydawnictwo WAM, Kraków 2005, s. 9-21.

Anzenbacher A., Co oznacza , godność cztowieka”?, „Horyzonty Wychowania” 2006, t. 5, nr 9, s. 53-71. 
Bagrowicz J., Aksjomat wiary jako fundament oddziatywań dydaktyczno-wychowawczych, w: Wieloptaszczyznowe wsparcie cztowieka we wspótczesnej pedagogii. Ksiega jubileuszowa dedykowana księdzu biskupowi Antoniemu Dtugoszowi, red. N. Pikuła, WSFP Ignatianum - Wydawnictwo WAM, Kraków 2011, s. 141-155.

Bagrowicz J., Wychowanie cztowieka jako osoby w swietle pedagogiki chrześcijańskiej, w: Pedagogika chrześcijańska. Tradycja, wspótczesność, nowe wyzwania, red. J. Michalski, A. Zakrzewska, Wydawnictwo Adam Marszałek, Toruń 2010, s. 48-63.

Bazylak J., Postawy religijne mtodzieży $i$ ich zwiazki z wybranymi elementami osobowości, ATK, Warszawa 1984.

Berner U., Religia, w: Leksykon religii, red. F. König, H. Waldenfels, tłum. P. Pachciarek, Verbinum, Warszawa 1997, s. 392-393.

Bochenek K., Kategoria życia osobowego fundamentem wychowania, w: Dzisiejszy katechizowany. Stan aktualny i wyzwania, red. J. Stala, Wydawnictwo WAM, Kraków 2002, s. 50-63.

Boużyk M.M., Wychowanie otwarte na religię. Polska Szkota Filozofii Klasycznej o roli religii w wychowaniu, Wydawnictwo UKSW, Warszawa 2013.

Brezinka W., Wychowanie i pedagogika w dobie przemian kulturowych, tlum. J. Kochanowicz, Wydawnictwo WAM, Kraków 2005.

Brezinka W., Wychowywaí dzisiaj. Zarys problematyki, tłum. J. Kochanowicz, Wydawnictwo WAM, Kraków 2007.

Buckley M.J., Ateizm w sporze z religiq, tłum. M. Frankiewicz, Wydawnictwo WAM, Kraków 2009.

Chlewiński Z., Stanowski A., Cztowiek - interpretacja scjentystyczno-kulturowa, w: Encyklopedia katolicka, t. 3, red. R. Łukaszyk, L. Bieńkowski, F. Gryglewicz, Towarzystwo Naukowe KUL, Lublin 1979, kol. 910-914.

Chmielewski M., Duchowośś, w: Leksykon duchowości katolickiej, red.M. Chmielewski, Wydawnictwo „M”, Lublin - Kraków 2002, s. 226-232.

Cichosz W., Możliwości dialogu wychowania chrześcijańskiego ze wspótczesna edukacja polskq, Wydawnictwo „Bernardinum”, Pelplin 2013.

Cichosz W., Pedagogia wiary we wspótczesnej szkole katolickiej, Wydawnictwo Typo 2, Warszawa 2010.

Cichosz W., Wychowanie chrześcijańskie wobec postmodernistycznej prowokacji, Zakłady Graficzne im. KEN, Gdańsk 2001.

Czarkowski J., Oblicza personalizmów. Konfrontacja antropologii filozoficznej E. Mouniera i P. Teilharda de Chardin, Wydawnictwo UMK, Toruń 1994.

Daniluk M., Duchowość chrześcijańska, w: Encyklopedia katolicka, t. 4, red. R. Łukaszyk, L. Bieńkowski, F. Gryglewicz, Towarzystwo Naukowe KUL, Lublin 1989, kol. 317-330.

Dyczewski L., Miejsce i funkcja wartości w kulturze, „Keryks” 2008, t. 7, s. $57-88$.

E. Josef Korherr - Studien zur religiösen Erziehung und Bildung, red. E. Rauscher, H.-F. Angel, M. Langer, Verlag Dr. Kovač, Hamburg 2008. 
Fleming D.L., Czym jest duchowość ignacjańska?, tłum. D. Piórkowski, Wydawnictwo WAM, Kraków 2013.

Fraas H.-J., Religia w procesie rozwoju osobowego dziecka, „Horyzonty Wiary” 1995 , t. 6 , nr 2, s. 45-56.

Gałdowa A., Nelicki A., O możliwościach i warunkach bycia twórczym z perspektywy aksjologicznej teorii wartości, „Zeszyty Naukowe Uniwersytetu Jagiellońskiego. Prace Psychologiczne"1993, z. 8, s. 7-28.

Goldman R., Vorfelder des Glaubens. Kindgemäße religiöse Unterweisung, Neukirchen Verlag, Vluyn 1972.

Góralczyk P., Wychowawcza etyka seksualna, Wydawnictwo Apostolicum, Ząbki 2000.

Granat W., Personalizm chrześcijański. Teologia osoby ludzkiej, Wydawnictwo św. Wojciecha, Poznań 1985.

Griffith J.L., Griffith M.E., Odkrywanie duchowości w psychoterapii, tłum. K. Gdowska, Wydawnictwo WAM, Kraków 2008.

Grom B., Psychologia religii, tłum. H. Machoń, Wydawnictwo WAM, Kraków 2009.

Grzebień L., Pedagogika ignacjańska na tle innych pedagogik zakonnych (refleksje nad dziejami szkolnictwa polskiego), w: Pedagogika ignacjańska. Historia, teoria, praktyka, red. A. Królikowska, WSFP Ignatianum - Wydawnictwo WAM, Kraków 2010, s. 107-128.

Hejnicka-Bezwińska T., Pedagogika ogólna, Wydawnictwa Akademickie i Profesjonalne, Warszawa 2008.

Hilger G., Leimgruber S., Ziebertz H.-G., Religionsdidaktik. Ein Leitfaden für Studium Ausbildung und Beruf, Kösel Verlag, München 2001.

Horowski J., Wychowanie moralne wedtug pedagogiki neotomistycznej, Wydawnictwo Naukowe UMK, Toruń 2015.

Jan Paweł II, Encyklika „Fides et ratio”, Watykan 1998.

Jasionek S., Uprawnienia i zobowiazania cztowieka, Wydawnictwo „Regina Poloniae”, Częstochowa 1999.

Jeziorański M., Wychowawcza wartość wspólnoty w odniesieniu do wybranych koncepcji antropologicznych, „Acta Universitatis Nicolai Copernici. Nauki Humanistyczno-Społeczne. Pedagogika” 2014, z. 422, s. 28-47.

Kazimierczak P., Personalistyczna koncepcja wychowania w nauczaniu Jana Pawta II, WSFP Ignatianum - Wydawnictwo WAM, Kraków 2003.

Kiereś B., Podstawy antropologiczne pedagogiki personalistycznej, w: Antropologiczna pedagogika ogólna, red. M. Nowak, P. Magier, I. Szewczak, Wydawnictwo „Gaudium”, Lublin 2010, s. 95-102.

Körtner U.H.J., Wiederhehr der Religion? Das Christentum zwischen neuer Spiritualität und Gottvergessenheit, Gütersloher Verlagshaus, Gütersloh 2006.

Kot T., Duch w Biblii, „Horyzonty Wychowania” 2007, t. 6, nr 11, s. 81-90.

Kowalczyk S., Krajewski R., Osoba, w: Encyklopedia katolicka, t. 14, red. E. Gigilewicz, Towarzystwo Naukowe KUL, Lublin 2010, kol. 900-904. 
Krąpiec A., Cztowiek - interpretacja filozoficzna, w: Encyklopedia katolicka, t. 3, red. R. Łukaszyk, L. Bieńkowski, F. Gryglewicz, Towarzystwo Naukowe KUL, Lublin 1979, kol. 914-917.

Karczewska J., Integralne wychowanie - chrześcijańska koncepcja Stefana Kunowskiego, Uniwersytet Jana Kochanowskiego, Kielce 2012.

Krąpiec M.A., Cztowiek - dramat natury i osoby, w: Wychowanie personalistyczne. Wybór tekstórw, red. F. Adamski, Wydawnictwo WAM, Kraków 2005, s. 23-40.

Krąpiec M.A., Cztowiek bytem osobowym, w: Wychowanie na rozdrożu. Personalistyczna filozofia wychowania, red. F. Adamski, Wydawnictwo UJ, Kraków 1999, s. 81-83.

Kunowski S., Podstawy wspótczesnej pedagogiki, Wydawnictwo Salezjańskie, Łódź 1981.

Kunstmann J., Rückehr der Religion. Glaube, Gott und Kirche neu verstehen, Gütersloher Verlagshaus, Gütersloh 2010.

Ladaria L.F., Wprowadzenie do antropologii teologicznej, thum. A. Baron, Wydawnictwo WAM, Kraków 2002.

Lombaerts H., Edukacja z perspektywy europejskiej, „Horyzonty Wychowania" 2002, t. 2, nr 3, s. 165-179.

Łobocki M., Wychowanie moralne w zarysie, Oficyna Wydawnicza „Impuls”, Kraków 2002.

Marek Z., Duchorwośc, religia i wychowanie, „Pedagogika Społeczna” 2015, t. 14, nr 1(55), s. 9-22.

Marek Z., Podstawka K., Wartości moralne (ujecie pedagogiczne), w: Encyklopedia aksjologii pedagogicznej, red. K. Chałas, A. Maj, Polskie Wydawnictwo Encyklopedyczne, Radom 2016, s. 1251-1254.

Marek Z., Podstawy wychowania moralnego, WSFP Ignatianum - Wydawnictwo WAM, Kraków 2005.

Marek Z., Potencjat religijny wnoszony do wychowania integralnego, „Pedagogika Społeczna" 2015, t. 14, nr 4(58), s. 9-20.

Marek Z., Religia pomoc czy zagrożenie dla edukacji?, Wydawnictwo WAM, Kraków 2014.

Marszałek L., Duchowoś́ dziecka. Znaczenia - perspektywy - konteksty w pedagogice przedszkolnej, Szkoła Wyższa im. Bogdana Jańskiego, Warszawa 2013.

Maslow A.H., Motywacja i osobowwośc, tłum. P. Sawicka, PAX, Warszawa 1990.

Mądrzycki T., Psychologiczne prawidtowości ksztattowania sie postaw, $\mathrm{Wy}-$ dawnictwa Szkolne i Pedagogiczne, Warszawa 1977.

Mette N., Religionspädagogik, Patmos Verlag, Düsseldorf 1994.

Meurer T., Duchowość jako zamiennik religii? Wyprawy w mgliste pogranicze religii i duchowosici, „Keryks”2011, t. 10, s. 147-159.

Michalski J., Edukacja i religia jako zródto rozwoju egzystencjalno-kognitywnego. Studium hermeneutyczno-krytyczne, Wydawnictwo UMK, Torun 2004. 
Michałowski S.C., Pedagogia personalistyczna wsparciem ksztattującego się systemu wychowania u początków XXI wieku, w: Nowe konteksty (dla) edukacji alternatywnej XXI wieku, Oficyna Wydawnicza „Impuls”, Kraków 2001, s. 633-647.

Milerski B., Hermeneutyka pedagogiczna. Perspektywy pedagogiki religii, Wydawnictwo Naukowe ChAT, Warszawa 2011.

Mółka J., W nurcie personalistycznego wychowania, „Rocznik Wydziału Pedagogicznego WSFP Ignatianum" 2003, s. 71-86.

Nikitorowicz J., Tradycja, w: Encyklopedia pedagogiczna XXI wieku, t. 6, red. T. Pilch, Wydawnictwo Akademickie „Żak”, Warszawa 2007, s. 773.

Niparko R., Wychowanie religijne jako wychowanie humanistyczne - perspektywa personalistyczna, „Paedagogia Christiana” 2003, nr 2(12), s. 9-22.

Nowak M., Osoba i wartość w pedagogice ogólnej, w: Antropologiczna pedagogika ogólna, red. M. Nowak, P. Magier, I. Szewczak, Wydawnictwo „Gaudium”, Lublin 2010, s. 41-56.

Nowak M., Pedagogika personalistyczna, w: Pedagogika, red. Z. Kwieciński, B. Śliwerski, Wydawnictwo Naukowe PWN, Warszawa 2005, s. 232-247.

Nowak M., Teorie i koncepcje wychowania, Wydawnictwa Akademickie i Profesjonalne, Warszawa 2008.

Olbrycht K., Wychowanie do wartości - w centrum aksjologicznych dylematów wspótczesnej edukacji, „Paedagogia Christiana” 2009, nr (2)24, s. 89-104.

Olchanowski T., Duchowośc i narcyzm, Wydawnictwo Psychologii i Kultury Eneteia, Warszawa 2006.

Osoba, w: Praktyczny stownik biblijny, red. A. Grabner-Haider, tłum. T. Mieszkowski, P. Pachciarek, PAX - Wydawnictwo Księży Pallottynów, Warszawa 1994, s. 907.

Pawluczuk W., Duchowość, w: Leksykon socjologii religii. Zjawiska-badaniateorie, red. M. Libiszowska-Żółtkowska, J. Mariański, Verbinum, Warszawa 2004, s. 90.

Prężyna W., Funkcja postawy religijnej w osobowości cztowieka, Redakcja Wydawnictw KUL, Lublin 1981.

Prężyna W., Intensywność postawy religijnej, a osobowość, Towarzystwo Naukowe KUL, Lublin 1973.

Schulz R., Wyktady z pedagogiki ogólnej, t. 2: O integralnq wizje cztowieka i jego rozwoju, Wydawnictwo UMK, Torun 2007.

Rahner K., Vorgrimler H., Maty stownik teologiczny, tłum. T. Mieszkowski, P. Pachciarek, Pax, Warszawa 1987.

Rusecki M., Wychowanie religijne w rodzinie, w: Religijno-moralny wymiar rozwoju $i$ wychowania, red. A. Rynio, K. Braun, A. Lendzion, D. Opozda, Wydawnictwo KUL, Lublin 2012, s. 229-235.

Sakowicz E., Religioznawstwo, Polihymnia, Lublin 2009.

Sesboüé B., Wierzę. Wezwanie do wiary katolickiej dla kobiet i mężczyzn XXI wieku, tłum. M. Żurowska, Wydawnictwo Księży Marianów - Księgarnia św. Wojciecha, Warszawa - Poznań 2000. 
Simon W., Pedagogika religii w Niemczech, w: Leksykon pedagogiki religii, red. C. Rogowski, Verbinum, Warszawa 2007, s. 567.

Słotwińska H., Religia i religijność, w: Leksykon pedagogiki religii, Verbinum, Warszawa 2007, s. 670-671.

Stańkowski B., Salezjański system wychowania mtodzieży - możliwe wypaczenia, „Seminare” 2011, nr 30, s. 187-194.

Surzykiewicz J., Religia, religijnośc i duchowość jako zasoby osobowe i kapitat spoteczny w pedagogice spotecznej/pracy socjalnej, „Pedagogika Społeczna” 2015, t. 14, nr 1(55), s. 23-71.

Szacki J., Tradycja, w: Stownik spoteczny, red. B. Szlachta, Wydawnictwo WAM, Kraków 2004, s. 1497.

Szewczyk W., Kim jest cztowiek. Zarys antropologii filozoficznej, Biblos, Tarnów 1994.

Ślipko T., Zarys etyki ogólnej, Wydawnictwo WAM, Kraków 2002.

Śliwerski B., Pedagogika bez transcendencji, w: Pedagogika ignacjańska wobec wyzwań wspótczesnego humanizmu, red. W. Pasierbek, WSFP Ignatianum - Wydawnictwo WAM, Kraków 2008, s. 79-137.

Śnieżyński M., Dialog edukacyjny, Wydawnictwo Naukowe PAT, Kraków 2001.

Teinert Z., Osoba, w: Leksykon pedagogiki religii, C. Rogowski, Verbinum, Warszawa 2007, s. 494-498.

Theil-Bielańska D., Osoba jako podmiot wychowania w świetle koncepcji personalizmu integralnego ks. Wicentego Granata, w: Chrześcijańskie inspiracje w pedagogice, red. J. Kostkiewicz, Wydawnictwo UJ, Kraków 2011, s. 79-90.

Waldenfels H., Fascynacja chrześcijaństwem, „Horyzonty Wiary” 1997, t. 8, nr 2, s. 3-16.

Waldenfels H., O Bogu, Jezusie Chrystusie i Kościele dzisiaj, tłum. A. Paciorek, Księgarnia św. Jacka, Katowice, 1993.

Wiseman J., Historia duchowości chrześcijanskiej. Wybrane zagadnienia, tłum. A. Wojtasik, Wydawnictwo WAM, Kraków 2009.

Witek S., Duchowość religijna, w: Encyklopedia katolicka, t. 4, red. R. Eukaszyk, L. Bieńkowski, F. Gryglewicz, Redakcja Wydawnictw KUL, Lublin 1989, kol. 330-334.

Zarzycki S., Cztowiek jako podmiot w ujęciu teologicznym, „Paedagogia Christiana” 2009, nr (2)24, s. 25-37.

Zdybicka Z., Transcendentne odniesienie cztowieka, w: Wychowanie personalistyczne. Wybór tekstów, red. F. Adamski, Wydawnictwo WAM, Kraków 2005, s. 69-88.

Ziebertz H.-G., Heil S., Antropologiczne podstawy ksztatcenia religijnego, „Horyzonty Wychowania” 2002, t. 1, nr 1, s. 129-151.

Ziebertz H.-G., Heil S., Antropologische Grundlage Religioesen Lernens, „Horyzonty Wychowania” 2002, t. 1, nr 1, s. 107-127.

Zięba S., Cztowiek. 2. Pochodzenie, w: Leksykon pedagogiki religii, red. C. Rogowski, Verbinum, Warszawa 2007, s. 77-99. 
Zimoń H., Typologia, w: Encyklopedia katolicka, t. 16, red. E. Gigilewicz i in., Towarzystwo Naukowe KUL, Lublin 2012, kol. 1394-1401.

Zoll A., Cztowiek jako podmiot wolności i praw w jednoczacej sie Europie, w: Cztowiek w jednoczacej się Europie, red. A. Królikowska, WSFP Ignatianum - Wydawnictwo WAM, Kraków 2004, s. 19-34.

Zulehner P.M., Religia jako mega trend, „Keryks” 2003, t. 2, nr 1, s. 21-35.

Zuziak W., Aksjologia Louisa Lavelle'a wobec ponowoczesnego kryzysu wartości, Wydawnictwo WAM, Kraków 2012.

Zwyczaj, w: Wielka encyklopedia PWN, t. 30, red. J. Wojnowski, Wydawnictwo Naukowe PWN, Warszawa 2005, s. 484.

Żurakowski B., Humanizm pedagogiki kultury, w: Pedagogika kultury - wychowanie do wyboru wartości, red. B. Żurakowski, Oficyna Wydawnicza „Impuls”, Kraków 2003, s. 97-104.

\section{ADRES DO KORESPONDENCJI:}

Prof. dr hab. Zbigniew Marek SJ

Akademia Ignatianum w Krakowie

Wydział Pedagogiczny

Instytut Nauk o Wychowaniu

z.marek@jezuici.pl 